\title{
Erbb4 Deletion from Medium Spiny Neurons of the Nucleus Accumbens Core Induces Schizophrenia-Like Behaviors via Elevated $\mathrm{GABA}_{\mathrm{A}}$ Receptor $\alpha 1$ Subunit Expression
}

\author{
Hong-Yan Geng, ${ }^{\star}$ Jing Zhang, ${ }^{\star}$ Jian-Ming Yang, Yue Li, Ning Wang, Mao Ye, Xiao-Juan Chen, Hong Lian, \\ and Xiao-Ming Li \\ Department of Neurobiology, Institute of Neuroscience, Key Laboratory of Medical Neurobiology of the Ministry of Health, Joint Institute for Genetics and \\ Genome Medicine between Zhejiang University and University of Toronto, Collaborative Innovation Center for Brain Science, Zhejiang University School of \\ Medicine, Hangzhou, Zhejiang Province, 310058 China
}

Medium spiny neurons (MSNs), the major GABAergic projection neurons in the striatum, are implicated in many neuropsychiatric diseases such as schizophrenia, but the underlying mechanisms remain unclear. We found that a deficiency in Erbb4, a schizophrenia risk gene, in MSNs of the nucleus accumbens (NAc) core, but not the dorsomedial striatum, markedly induced schizophrenia-like behaviors such as hyperactivity, abnormal marble-burying behavior, damaged social novelty recognition, and impaired sensorimotor gating function in male mice. Using immunohistochemistry, Western blot, RNA interference, electrophysiology, and behavior test studies, we found that these phenomena were mediated by increased $\mathrm{GABA}_{\mathrm{A}}$ receptor $\alpha 1$ subunit $\left(\mathrm{GABA}_{\mathrm{A}} \mathrm{R} \alpha 1\right)$ expression, which enhanced inhibitory synaptic transmission on MSNs. These results suggest that Erbb4 in MSNs of the NAc core may contribute to the pathogenesis of schizophrenia by regulating GABAergic transmission and raise the possibility that $\mathrm{GABA}_{\mathrm{A}} \mathrm{R} \alpha 1$ may therefore serve as a new therapeutic target for schizophrenia.

Key words: ErbB4; $\mathrm{GABA}_{\mathrm{A}}$ receptor; medium spiny neurons; nucleus accumbens core; schizophrenia

Significance Statement

Although ErbB4 is highly expressed in striatal medium spiny neurons (MSNs), its role in this type of neuron has not been reported previously. The present study demonstrates that Erbb4 deletion in nucleus accumbens (NAc) core MSNs can induce schizophrenia-like behaviors via elevated $\mathrm{GABA}_{\mathrm{A}}$ receptor $\alpha 1$ subunit $\left(\mathrm{GABA}_{\mathrm{A}} \mathrm{R} \alpha 1\right)$ expression. To our knowledge, this is the first evidence that ErbB4 signaling in the MSNs is involved in the pathology of schizophrenia. Furthermore, restoration of $\mathrm{GABA}_{\mathrm{A}} \mathrm{R} \alpha 1$ in the NAc core, but not the dorsal medium striatum, alleviated the abnormal behaviors. Here, we highlight the role of the NAc core in the pathogenesis of schizophrenia and suggest that $\mathrm{GABA}_{\mathrm{A}} \mathrm{R} \alpha 1$ may be a potential pharmacological target for its treatment.

\section{Introduction}

The striatum, the largest nucleus of the basal ganglia in the forebrain, is well known for its regulation of voluntary movement

\footnotetext{
Received Dec. 25, 2016; revised June 3, 2017; accepted June 19, 2017

Author contributions: H.-Y.G., J.Z., and X.-M.L. designed research; H.-Y.G., J.Z., J.-M.Y., Y.L., N.W., M.Y., and X.-J.C. performed research; H.-Y.G. and J.Z. analyzed data; H.-Y.G., H.L., and X.-M.L. wrote the paper.

This work was supported by the Key Project of the National Natural Science Foundation of China (Grant 31430034), the Major Research Plan of the National Natural Science Foundation of China (Grant 91432306), the National Key Research and Development Plan (Grant YFA050100), the Funds for Creative Research Groups of China (Grant 81221003), the Program for Changjiang Scholars and Innovative Research Team in University, Fundamental Research Funds for the Central Universities (X.-M.L.), and the National Natural Science Foundation of China (Grant 81471150 to J.-M.Y.). We thank Dr. Z. Josh Huang (Cold Spring Harbor Laboratory, Cold Spring Harbor, NY) and Dr. Miao He (Institutes of Brain Science, Fudan University, Shanghai, China) for kindly providing DIx5/6-flp mice. We thank Bo Li (Cold Spring Harbor Laboratory) for kindly providing the pAAV-fDI0-Cre-GFP and pAAV-fDI0-GFP plasmids and Cary Lai (Department of Psychological and Brain Sciences, Indiana University) for the ErbB4 antibody.

The authors declare no competing financial interests.

*H.-Y.G. and J.Z. contributed equally to this work.

Correspondence should be addressed to Xiao-Ming Li, Institute of Neuroscience, Research Building, Room A507, 866 Yuhangtang Road, Hangzhou, 310058 China. E-mail: lixm@zju.edu.cn.
}

and cognition and nearly $95 \%$ of striatal neurons are GABAergic medium spiny neurons (MSNs) (Kreitzer, 2009; Crittenden and Graybiel, 2011). The striatum consists of the nucleus accumbens (NAc) in the ventral area and the caudate putamen $(\mathrm{CPu})$ in the dorsal area. The NAc, which consists of the core and the shell, is a classical regulator of reward-related behaviors (Russo and Nestler, 2013). In addition, a recent review described the NAc as an interface among cognition, emotion, and action (Floresco, 2015). In contrast, the $\mathrm{CPu}$, which is composed of the dorsolateral striatum (DLS) and dorsomedial striatum (DMS), is mainly involved in motivation, decision making, goal direction, and habituation behaviors (Haber, 2003; Balleine et al., 2007; Jahanshahi et al., 2015). MSN dysfunction in either the NAc or the CPu has been implicated in the pathogenesis of neuropsychiatric diseases such as 
schizophrenia, obsessive-compulsive disorder, and Parkinson's disease (Mehler-Wex et al., 2006; Rauch et al., 2006; Simpson et al., 2010; Okada et al., 2016). However, the mechanisms underlying how MSN dysfunction is involved in neuropsychiatric diseases including schizophrenia remain unclear.

Erbb4 is a susceptibility gene of schizophrenia (Mei and Xiong, 2008). Various Erbb4 SNPs associated with schizophrenia have been revealed by genome-wide studies (Nicodemus et al., 2006; Silberberg et al., 2006; Shi et al., 2009; Lu et al., 2010; Agim et al., 2013) and Erbb4 microdeletions or microduplications were detected in patients with schizophrenia (Walsh et al., 2008). In addition to human genetic studies, evidence from Erbb4-mutant mice further validated the possible causal effect of ErbB4 malfunction to schizophrenia. Erbb4 mutant mice showed "schizophrenia-like" behavioral deficits, in contrast to the overtly normal performance by Erbb2- and Erbb3-heterozygous/null mice (Gerlai et al., 2000; Golub et al., 2004). Among the various brain regions and neuronal types where Erbb4 is expressed, ErbB4 function in the cortical and hippocampal neurons has been studied intensely (Hahn et al., 2006; Pitcher et al., 2011; Del Pino et al., 2013; Mitchell et al., 2013; Seshadri et al., 2015; Zhou et al., 2015b), but relatively little is known about its role in other brain areas. We found surprisingly high ErbB4 expression in MSNs in the striatum and investigated its potential roles in the striatal neurons in the regulation of animal behaviors.

In the current study, we deleted Erbb4 specifically in MSNs of the NAc core and observed schizophrenia-like behaviors. Furthermore, by combining Western blotting, electrophysiology, RNA interference, and immunohistochemistry, we found that $\mathrm{GABA}_{\mathrm{A}}$ receptor $\alpha 1$ subunit $\left(\mathrm{GABA}_{\mathrm{A}} \mathrm{R} \alpha 1\right)$ expression was elevated in MSNs of the NAc core, which accounts for the behavioral phenotypes induced by ErbB4 deficiency. These results indicate that ErbB4 in MSNs of the NAc core plays an important role in mediating the pathogenesis of schizophrenia.

\section{Materials and Methods}

Mice. The Dlx5/6-Cre;Erbb $4^{\text {loxp/loxp }}$ line was generated by crossing Dlx5/ 6-Cre mice (The Jackson Laboratory; Zerucha et al., 2000) with Erbb4 $4^{\text {loxp/loxp }}$ mice (Mutant Mouse Regional Resource Center). The Dlx5/6-Cre;Ai9 line was obtained by crossing Dlx5/6-Cre mice with Ai9 mice (The Jackson Laboratory; Vullhorst et al., 2009) that express tdTomato under the control of a Cre-dependent promoter. For ErbB4 detection in cKO mice, we crossed Dlx5/6-Cre;Erbb4 $4^{\text {loxp/loxp }}$ mice with Ai9 mice to label the MSNs with tdTomato. Dlx5/6-flp;Erbb4 $4^{\text {loxp/loxp }}$ mice were acquired by crossing Dlx5/6-flp mice (kindly provided by Z. Josh Huang, Cold Spring Harbor Laboratory, Cold Spring Harbor, NY, and Dr. Miao He, Institutes of Brain Science, Fudan University, Shanghai, China) with Erbb4 ${ }^{\text {loxp/loxp }}$ mice. Dlx5/6-flp;Ai65 mice were obtained by crossing Dlx5/6-flp mice with Ai65 mice (The Jackson Laboratory; Madisen et al., 2015). Cells in Ai65 mice show red fluorescence only when Cre and Flp recombinases are present simultaneously. Mice were housed under a $12 \mathrm{~h}$ light/dark cycle and had access to food and water ad libitum. All mouse lines were crossed with the C57BL/6J background for $>10$ generations. Only male mice $8-13$ weeks of age were used for all behavioral tests, immunohistochemistry, Western blot, and electrophysiology studies. All animal use procedures were reviewed and approved by the Animal Advisory Committee at Zhejiang University and the National Institutes of Health's Guidelines for the Care and Use of Laboratory Animals.

Tissue sample preparation. Protein samples were prepared from 8- to 13-week-old male mice. Mice were decapitated rapidly and the brains were quickly removed on ice. Two knife blades were tightened together with $1 \mathrm{~mm}$ interstice to insure the tissue thickness limited to $1 \mathrm{~mm}$. After removing the olfactory bulb, the second $1 \mathrm{~mm}$ coronal section was selected to dissect the NAc core part and the second and third $1 \mathrm{~mm}$ sections were used for the DMS separation. Surrounding anterior com- missure $0.5 \mathrm{~mm}$ was selected as the NAc core tissue. After disassociating the dorsal striatum by cutting along the corpus callosum and lateral ventricle, the medial $1 \mathrm{~mm}$ part was selected as the DMS tissue. All corresponding brain regions were dissected bilaterally on an ice-cooled plate. Dissected brain tissues were then transferred to a $-80^{\circ} \mathrm{C}$ freezer. Separated tissues were homogenized with an electrical disperser (Wiggenhauser) after $30 \mathrm{~min}$ in RIPA lysis buffer with protease and phosphatase inhibitors (Beyotime Biotechnology) containing the following: $20 \mathrm{~mm}$ Tris, pH 7.5, $150 \mathrm{~mm} \mathrm{NaCl}, 1 \%$ Triton X-100, $2.5 \mathrm{~mm}$ sodium pyrophosphate, $1 \mathrm{~mm}$ EDTA, $1 \% \mathrm{Na}_{3} \mathrm{VO}_{4}, 0.5 \mu \mathrm{g} / \mathrm{ml}$ leupeptin, and 1 mu phenylmethanesulfonyl fluoride. The tissue homogenates were then centrifuged at $12,000 \times g$ for $10 \mathrm{~min}$ at $4^{\circ} \mathrm{C}$. All protein sample concentrations were determined with the bicinchoinic acid assay (Beyotime Biotechnology).

Western blot assays. Western blot assay procedures were based on those used in our previous studies (Li et al., 2011; Yang et al., 2013). Loading buffer (5×; Beyotime Biotechnology) was added to each sample (4:1 sample:loading buffer) before boiling for $5 \mathrm{~min}$. Protein samples were run on $10 \%$ SDS-polyacrylamide gels and then transferred to polyvinylidene difluoride membranes. After blocking in 3\% nonfat milk for $1 \mathrm{~h}$ at room temperature (RT), membranes were incubated with the respective primary antibodies at $4^{\circ} \mathrm{C}$ overnight (rabbit anti-ErbB4, 1:2000, ab32375, Abcam, RRID: AB 731579; rabbit anti-GABA ${ }_{\mathrm{A}} \mathrm{R} \alpha 1,1: 1000,06-868$, Millipore, RRID: $\mathrm{AB}_{-}$ 310272; rabbit anti-GABA $\mathrm{A} \alpha 2,1: 1000$, ab72445, Abcam, RRID: AB_1268929; rabbit anti-GABA ${ }_{A} R \quad \beta 2,1: 1000$, ab8340, Abcam, RRID: AB_306495; goat anti-gephyrin, 1:500, sc-6411, Santa Cruz Biotechnology, RRID: AB_640962; rabbit anti-GAPDH, 1:5000, 5174, Cell Signaling Technology, RRID: AB_10622025; Mouse anti GluN1, 1:500, 05-432, Millipore, RRID: AB_10015247; rabbit anti GluN2A, 1:500, 07-632, Millipore, RRID: AB_11213002; rabbit anti GluN2B, 1:1000, 06-600, Millipore, RRID: AB_310193). After washing 3 times in $0.1 \%$ Tween 20 in TBS, the membranes were incubated with horseradish peroxidaseconjugated secondary antibodies in 3\% nonfat milk for $1 \mathrm{~h}$ at RT and visualized with an ECL kit (Thermo Scientific). Quantitative analysis was performed with ImageJ software. Each experiment was performed at least three times. The data for statistical analyses were from at least three mice per group.

Immunohistochemistry. Immunohistochemistry was performed on 40$\mu \mathrm{m}$-thick sections as described previously (Yang et al., 2013). After deep anesthesia, the relevant male mice were perfused with ice-cold saline followed by $4 \%$ paraformaldehyde (Christoffel et al., 2015) in $0.1 \mathrm{M}$ PBS, $\mathrm{pH}$ 7.4. The brains were removed, postfixed overnight in $4 \% \mathrm{PFA}$ at $4^{\circ} \mathrm{C}$, and transferred to $30 \%$ sucrose in $0.1 \mathrm{M}$ PBS, $\mathrm{pH}$ 7.4. Coronal sections $(40 \mu \mathrm{m})$ were cut on a cryostat (Leica CM3050 S) and stored in $0.1 \mathrm{M}$ PBS. The sections were incubated in blocking buffer containing $3 \%$ bovine serum albumin and 5\% normal goat serum in $0.2 \%$ Triton X-100/PBS (PBST) for $1 \mathrm{~h}$ at RT and then with primary antibodies in blocking buffer overnight at $4^{\circ} \mathrm{C}$ (mouse anti-ErbB4, 1:500, a kind gift from Cary Lai; rabbit anti-DARPP32, 1:2000, 2306S, Cell Signaling Technology, RRID: AB_823479; mouse anti-parvalbumin (PV), 1:5000, 235, Swant, RRID: AB_10000343; rabbit anti-choline acetyltransferase (ChAT, a cholinergic neuronal marker), 1:400, 297 013, Synaptic Systems, RRID:AB_2620040). After three washes with PBST, sections were incubated with Alexa Fluor 488or Alexa Fluor 543-conjugated secondary antibodies at RT for $1 \mathrm{~h}$. After another three washes in PBST, sections were mounted with Prolong anti-fade medium (Invitrogen).

Perisomatic $G A B A_{A}$ receptor $\alpha 1$ subunit analysis. Sections were processed identically and immunohistochemical experiments were repeated at least three times to ensure reliability. Images of the NAc core were captured from a single confocal plane with $60 \times$ oil-immersion objective lens (numerical aperture 1.4) on an inverted confocal microscope (Nikon A1R). All images were acquired using the same parameters. Gray levels of perisomatic $\mathrm{GABA}_{\mathrm{A}} \mathrm{R} \alpha 1(<2 \mu \mathrm{m}$ away from the soma membrane) were measured using ImageJ software and the nucleus of each neuron was selected as the background reference region. Image capture and analysis were performed by investigators who were blind to the genotype and virus injection.

Electrophysiology analysis. Male mice (8-13 weeks old) were deeply anesthetized and decapitated. The brain was quickly removed and placed 
in ice-cold artificial CSF (ACSF) containing the following (in mM): 125 $\mathrm{NaCl}, 2.5 \mathrm{KCl}, 11 \mathrm{D}$-glucose, $26 \mathrm{NaHCO}_{3}, 1.25 \mathrm{NaH}_{2} \mathrm{PO}_{4}, 2 \mathrm{CaCl}_{2}$, and 2 $\mathrm{MgCl}_{2}$. The solution was bubbled with $95 \% \mathrm{O}_{2} / 5 \% \mathrm{CO}_{2}$ to maintain a $\mathrm{pH}$ of $\sim 7.4$. Coronal slices $(300 \mu \mathrm{m})$ containing striatum were cut on a microtome (Leica VT1200S). The slices were stored for 30-45 min at $37^{\circ} \mathrm{C}$ in oxygenated ACSF and then kept at RT.

Electrophysiology assay procedures were based on those used in our previous studies (Li et al., 2011; Yang et al., 2014). Individual slices were transferred to a recording chamber and fully submerged in continuously perfused $(2-3 \mathrm{ml} / \mathrm{min})$ oxygenated ACSF maintained at $34 \pm 2^{\circ} \mathrm{C}$. Recording neurons were all MSNs in the $\mathrm{CPu}$ or NAc identified by tdTomato-positive or virus transfected GFP-positive cells. To record miniature IPSCs (mIPSCs), we used pipette solution containing the following (in mM): $130 \mathrm{CsCl}, 4$ $\mathrm{NaCl}, 10$ TEA, 10 HEPES, $2 \mathrm{Na} 2-\mathrm{ATP}, 0.5 \mathrm{Na} 3-\mathrm{GTP}$, and 0.2 EGTA; $\mathrm{pH}$ was adjusted to 7.25 with $10 \mathrm{M} \mathrm{CsOH}$; tetrodotoxin $(1 \mu \mathrm{M}$; to block sodium current), DL-2-amino-5-phosphonopentanoic acid (50 $\mu \mathrm{M}$, Tocris Bioscience; to block NMDA receptors), and 6, 7-dinitroquinoxaline-2, $3(1 \mathrm{H}, 4 \mathrm{H})$-dione ( $20 \mu \mathrm{M}$, Tocris Bioscience; to block AMPA receptors) were present in the bath solution and neurons were voltage clamped at $-70 \mathrm{mV}$. To record mEPSCs, we used pipette solution containing the following (in mM): $130 \mathrm{CsMeSO}, 4 \mathrm{NaCl}, 10 \mathrm{TEA}, 10 \mathrm{HEPES}$, $2 \mathrm{Na} 2$-ATP, $0.5 \mathrm{Na} 3$-GTP, and 0.2 EGTA; pH was adjusted to 7.25 with $10 \mathrm{M} \mathrm{CsOH}$; tetrodotoxin ( $1 \mu \mathrm{M}$; to block sodium current); picrotoxin (100 $\mu \mathrm{m}$; to block GABAA receptors) were present in the bath solution and neurons were voltage clamped at $-70 \mathrm{mV}$. Recordings were started 2-3 min after a stable whole-cell configuration was obtained. Access resistance $(<20 \mathrm{M} \Omega)$ was not compensated and was monitored continually throughout each experiment. Recordings were terminated whenever input resistance increased $>30 \%$ or access resistance exceeded $20 \mathrm{M} \Omega$. mIPSCs under these conditions are inward. Signals were acquired using an Molecular Devices MultiClamp 700B amplifier controlled by Clampex 10.2 software via a Digidata 1440A interface (Molecular Devices). Responses were filtered at $2 \mathrm{kHz}$, digitized at $10 \mathrm{kHz}$, and analyzed using Clampfit 10.2 (Molecular Devices) and Mini Analysis 6.0 software (Synaptosoft). The rootmean-square noise level was 2-4 pA and a threshold of $12 \mathrm{pA}$ was used to detect and measure mIPSCs. Whole-cell recordings were acquired from the $\mathrm{CPu}$ and the NAc core. Collected events were averaged for amplitude and frequency measurements.

Behavior. For all behavior tests, only 8- to 13-week-old male mice were used and the number of mice for each behavior test is presented in the corresponding figure legend. The experimenter was blind to genotype while conducting and analyzing the experiments.

For the open-field test, the size of the open-field box was $45 \times 45 \times 45$ $\mathrm{cm}$. Mice were introduced into the center of the chamber at the beginning of the test and movements were recorded with a video camera for 15 $\min$. Speed $<2 \mathrm{~cm} / \mathrm{s}$ was defined as immobility. Locomotor activity was evaluated as the distance traveled per $5 \mathrm{~min}$ and the total distance.

For the marble bury test, similar to a previous study (Deacon, 2006), large empty cages $(40 \times 24 \times 20 \mathrm{~cm})$ for the marble-burying test were filled with bedding up to $4 \mathrm{~cm}$ from the cage floor and 20 blue marbles were positioned in $4 \times 5$ grid pattern throughout the cage. Mice were allowed to explore the cage freely for $30 \mathrm{~min}$ and then the number of successfully buried marbles was counted. A marble was defined as buried when $<25 \%$ of it was visible. The experiment was recorded with a digital video camera.

The three-chamber test comprised three phases. In the first phase, a mouse was placed in the three-chambered polycarbonate apparatus and allowed to explore freely for $10 \mathrm{~min}$ for habituation. In the second phase, the test mouse was gently placed in the center chamber with both gates to the side chambers closed. A stranger mouse (Stranger 1) was then introduced into one side chamber. Gates were then opened and the test mouse was allowed to explore the new environment freely for $10 \mathrm{~min}$. In the last phase, the test mouse was introduced into the center chamber, again with both gates closed, and another stranger mouse (Stranger 2) was placed in the remaining empty side chamber. The test mouse was allowed to explore the environment freely again for $10 \mathrm{~min}$. Time spent (or distance traveled) within $2 \mathrm{~cm}$ of each chamber was recorded for each session of the test. If a mouse showed preference to one side chamber in the first phase, it would be excluded from the test. The preference index was defined as the numerical difference between the time spent exploring the targets (Stranger1 vs Empty or Stranger 2 vs Stranger 1) divided by the total time spent exploring both targets.

For the prepulse inhibition (PPI) test, mice were placed in a clear Plexiglas cylinder in 1 of 2 SR-Lab System startle chambers (San Diego Instruments) for a 5 min acclimation period. A $70 \mathrm{~dB}$ broadband background noise was presented during acclimation and throughout the test session. During the test session, mice were presented with startle trials (20 $\mathrm{ms} 120 \mathrm{~dB}$ broadband sound pulse) and prepulse plus startle trials $(20 \mathrm{~ms}$ noise prepulse sound followed by a $20 \mathrm{~ms} 120 \mathrm{~dB}$ broadband sound pulse with a $100 \mathrm{~ms}$ interval). The prepulse plus startle trials were preceded and followed by five pulse-only trials, which were not included in the analyses. Test trials consisted of 10 trials of 3 different intensities $(5,10$, and 15 $\mathrm{dB}$ above background). Startle trials were performed 5 times and prepulse plus startle trials were performed 10 times with a variable interval of $5-60 \mathrm{~s}$ between each presentation. Startle amplitude was measured every $1 \mathrm{~ms}$ with a $60 \mathrm{~ms}$ period beginning at the onset of the startle stimulus. The peak startle amplitude over the sampling period was taken as the dependent variable. Whole-body startle responses were measured via vibrations transduced into analog signals by a piezoelectric unit attached to the platform on which the cylinders rested. Percentage PPI of startle was calculated as (startle response for startle-alone trials - startle response for prepulse and startle trials)/startle response for startle-alone trials $\times 100$.

Design and cloning of short hairpin RNA constructs. shRNA specifically targeting the mouse $\mathrm{GABA}_{\mathrm{A}}$ receptor $\alpha 1$ subunit (GenBank accession NC000077) was designed and cloned. A 19 nt small interfering RNA (siRNA) sequence (5'-CCACTGTCTTCACAAGAAT-3') was verified with a BLAST search. A nonrelated 19 nt sequence $\left(5^{\prime}\right.$-TTCTCCGAA CGTGTCACGT- $3^{\prime}$ ) was used as a scrambled control. The $\mathrm{GABA}_{\mathrm{A}} \mathrm{R} \alpha 1$ shRNA was cloned into the modified pAAV vector pSB0211 pMT3 containing a U6 promoter (Shiao Med Pharma Biotechnology) to drive shRNA expression and EF1 $\alpha$ to drive EGFP expression.

Stereotaxic surgery and viral infusion examination. AAV-shRNA- $\alpha 1$ GFP (and scrambled control virus) and AAV-fDIO-Cre-GFP (and control virus) were produced by Shiao Med Pharma Biotechnology. Two-month-old mice were anesthetized and placed in a stereotaxic system. Viruses were delivered with glass micropipettes. The stereotaxic coordinates were $\mathrm{AP}+0.5 \mathrm{~mm}, \mathrm{ML} \pm 1.9 \mathrm{~mm}$, and $\mathrm{DV}+3.2 \mathrm{~mm}$ for the dorsomedial striatum and $\mathrm{AP}+1.34 \mathrm{~mm}, \mathrm{ML} \pm 0.8 \mathrm{~mm}$, and $\mathrm{DV}+4.6$ $\mathrm{mm}$ for the NAc core. A total of $1 \mu \mathrm{l}$ of virus was injected bilaterally into the dorsomedial striatum within $20 \mathrm{~min}$ and $500 \mathrm{nl}$ of virus was injected into the NAc core within $10 \mathrm{~min}$. After surgery, mice were returned to the home cage and maintained for 3 weeks to ensure virus expression before behavioral tests were performed. To avoid the potential interference from off-target viral expression, brains from animals receiving injection were perfused, sectioned, and checked with a microscope under GFP fluorescence in the targeted region. For the NAc core, virus expression should be limited to the surrounding anterior commissure $0.5 \mathrm{~mm}$ area. For the DMS, virus expression should be limited to the medial $1 \mathrm{~mm}$ part of the $\mathrm{CPu}$. Those mice with inaccurate viral injection were excluded from all the relevant analysis.

Experimetal design and statistical analysis. To detect what kind of neurons were labeled in the Dlx5/6-cre-Ai9-tdTomato mice, we used three male mice for immunostaining of different neuron markers such as DARPP32, PV, and ChAT and calculated the percentage of each neuronal type in tdTomato-positive cells. For the ErbB4 deletion experiment, three control (Con) and three conditional knock-out (cKO) male mice were used for immunostaining to confirm that ErbB4 was knocked out in the $\mathrm{CPu}$ and NAc. Western blots using protein lysates from five Con and five cKO mice further confirmed our results. Both staining and Western blotting results were analyzed by unpaired two-tailed $t$ test for statistical difference between the two groups.

We next detected the behavior difference between 16 Con and $16 \mathrm{cKO}$ mice for open-field analysis, $13 \mathrm{Con}$ and $14 \mathrm{cKO}$ mice for three chamber exploration analysis, and $16 \mathrm{Con}$ and $15 \mathrm{cKO}$ mice for PPI analysis using two-way ANOVA with Bonferroni post hoc test. Fifteen Con mice and 18 cKO mice were used for the marble-burying test and 13 Con and $14 \mathrm{cKO}$ mice were used for the three chamber preference test and analyzed with unpaired two-tailed $t$ test. 

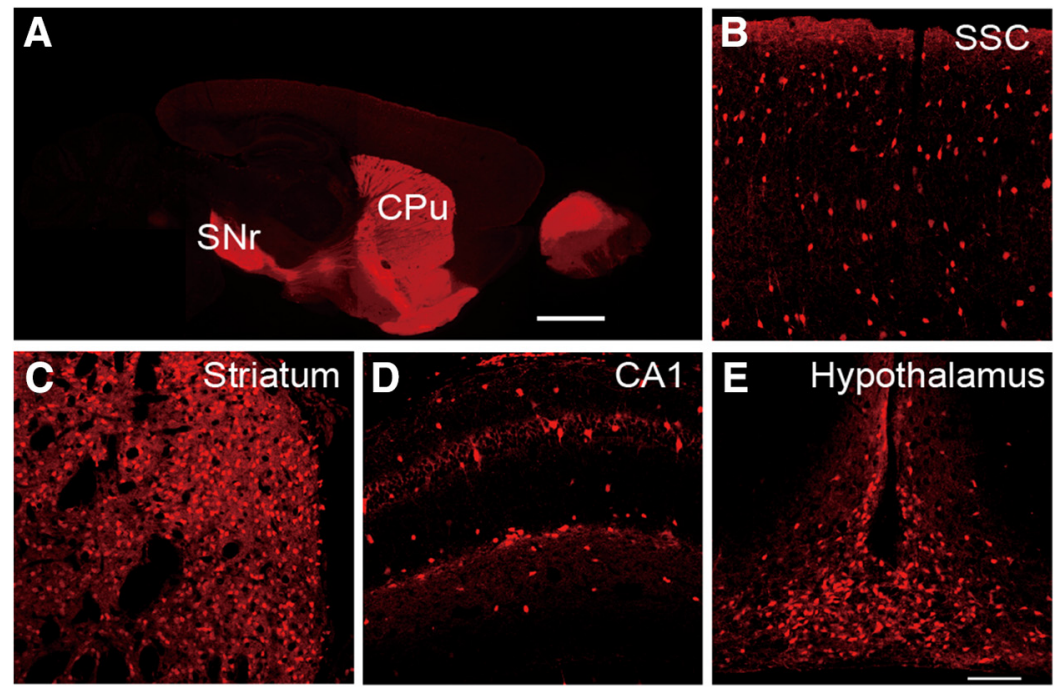

F
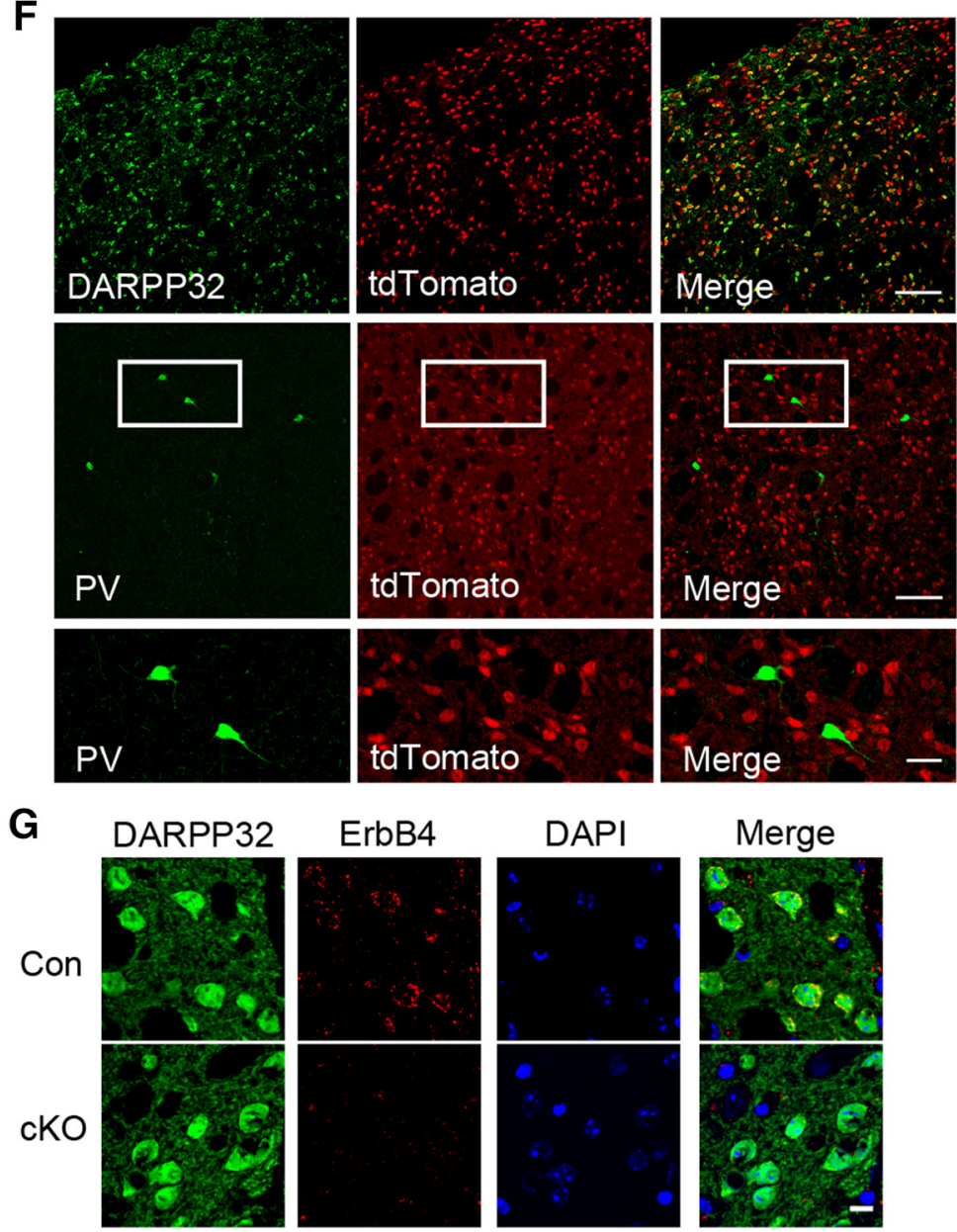

\section{Merge}

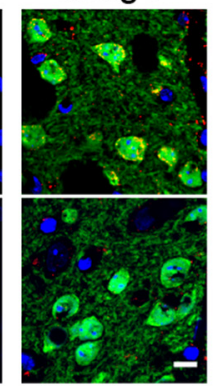

Figure 1. Additional Dlx5/6 labeling in D/x5/6-cre-Ai9-tdTomato mice and Erbb4 was also deleted in the CPu MSNs but not PV-expressing interneurons in CKO mice. $\boldsymbol{A}$, Sagittal section (ML $\pm 1.44 \mathrm{~mm}$ ) of adult Ai9;D/×5/6-cre report mice. tdTomatopositive neurons in somatosensory cortex $(\boldsymbol{B})$, striatum $(\boldsymbol{C})$, hippocampal $C A 1(\boldsymbol{D})$, and hypothalamus $(\boldsymbol{E})(n=3)$. SSC, Somatosensory cortex. Scale bars: $\boldsymbol{A}, 1 \mathrm{~mm} ; \boldsymbol{B}-\boldsymbol{E}, 100 \mu \mathrm{m} . \boldsymbol{F}$, DARPP32 staining to mark striatal MSNs in CPu. PV-expressing interneurons did not have labeled in Ai9;D/X5/6-cre report mice ( $n=1124$ cell of 3 mice). Scale bars: top and middle row, $100 \mu \mathrm{m}$; bottom row, zoom for white box in middle row, $30 \mu \mathrm{m}$. G, Staining of ErbB4 and DARPP32 in control and cKO from the CPu slices with DAPI indicated nuclei location ( $n=1512$ cells of 3 Con and 1457 cells of 3 cKO mice). Scale bar, $10 \mu \mathrm{m}$.

To figure out the underlying mechanism, expression levels of different postsynaptic protein were measured by Western blotting. Protein samples from five Con and five $\mathrm{cKO}$ mice for $\mathrm{GABA}_{\mathrm{A}} \mathrm{R} \alpha 1$, four Con and three $\mathrm{CKO}$ mice for $\mathrm{GABA}_{\mathrm{A}} \mathrm{R} \alpha 2$, three Con and three $\mathrm{CKO}$ mice for $\mathrm{GABA}_{\mathrm{A}} \mathrm{R} \beta 2$, four
Con and three cKO mice for gephyrin, three Con and three $\mathrm{CKO}$ mice for GluN2A, three Con and three cKO mice for GluN2B, and three Con and three cKO mice for GluN1 were used and compared them using unpaired two-tailed $t$ test. To detect ErbB4 and $\mathrm{GABA}_{\mathrm{A}} \mathrm{R} \alpha 1$ changes in different brain areas, we used five Con and five $\mathrm{cKO}$ mice for the NAc, three Con and three $\mathrm{CKO}$ mice for the $\mathrm{CPu}$, three Con and three $\mathrm{KOO}$ mice for the prefrontal cortex, three Con and three cKO mice for the hippocampus, and five Con and five cKO mice for the thalamus for Western blotting and compared them using unpaired two-tailed $t$ test. Immunostaining for the $\mathrm{GABA}_{\mathrm{A}} \mathrm{R} \alpha 1$ further verified the Western result though the comparison between 43 cells from four Con mice and 51 cells from five $\mathrm{cKO}$ mice by unpaired two-tailed $t$ test.

To detect synaptic transmission changes in cKO, we recorded mIPSCs. Fifteen cells from eight Con mice and 14 cells from seven cKO mice in the CPu and 18 cells from five Con mice and 22 cells from five cKO mice in the NAc were used to measure mIPSCs and compared using the Kolmogorov-Smirnov (K-S) $t$ test.

Because $\mathrm{GABA}_{\mathrm{A}} \mathrm{R} \alpha 1$ elevation was detected in the striatum, interfering with its expression may alleviate abnormal behaviors. For the $\mathrm{GABA}_{\mathrm{A}} \mathrm{R} \alpha 1 \mathrm{RNAi}$ virus validity, three Con mice with scrambled shRNA virus (Con-Scr); three cKO mice with scrambled shRNA virus (cKO-Scr), and three cKO mice receiving $\mathrm{GABA}_{\mathrm{A}} \mathrm{R} \alpha 1$ shRNA (cKO-shRNA) were used for the $\mathrm{CPu}$ immunoblots and analyzed by one-way ANOVA with Bonferroni post hoc test. Twenty-four cells from four $\mathrm{CKO}$-Scr mice and 50 cells from four cKO-shRNA mice were used for the NAc immunostaining confirmed $\mathrm{GABA}_{\mathrm{A}} \mathrm{R} \alpha 1$ interference effect after the results were tested by unpaired two-tailed $t$ test.

To detect behavior changes after $\mathrm{GABA}_{\mathrm{A}} \mathrm{R}$ $\alpha 1$ interference in the DMS, 12 Con-Scr mice, $12 \mathrm{cKO}-\mathrm{Scr}$ mice, and $10 \mathrm{cKO}$-shRNA mice were used for open-field analysis; 12 Con-Scr mice, eight $\mathrm{cKO}-\mathrm{Scr}$ mice, and nine cKOshRNA mice for three chamber analysis; and 12 Con-Scr mice, eight cKO-Scr mice, and nine cKO-shRNA mice for PPI analysis were analyzed by two-way ANOVA with Bonferroni post hoc test. Twelve Con-Scr mice, eight cKOScr mice, and nine cKO-shRNA mice were tested for marble-burying analysis and compared with one-way ANOVA with Bonferroni post hoc test.

To test behavior changes after $\mathrm{GABA}_{\mathrm{A}} \mathrm{R} \alpha 1$ interference in the NAc core, eight Con-Scr mice, $14 \mathrm{cKO}$-Scr mice, and $12 \mathrm{cKO}$-shRNA mice for open-field analysis; 11 Con-Scr mice, $12 \mathrm{cKO}$-Scr mice, and $13 \mathrm{cKO}$-shRNA mice for three chamber exploration analysis; and 10 Con-Scr mice, $14 \mathrm{cKO}-\mathrm{Scr}$ mice, and $14 \mathrm{cKO}$ shRNA mice for PPI analysis were used and data were analyzed by two-way ANOVA with Bonferroni post hoc test. Behavioral data from 12 Con-Scr mice, $15 \mathrm{cKO}-\mathrm{Scr}$ mice, and 14 cKO-shRNA mice for marble-burying analysis and 11 Con-Scr mice, $12 \mathrm{cKO}-\mathrm{Scr}$ mice, and $13 \mathrm{cKO}$-shRNA mice for the three chamber preference analysis were tested by one-way ANOVA with Bonferroni post hoc test. 
A

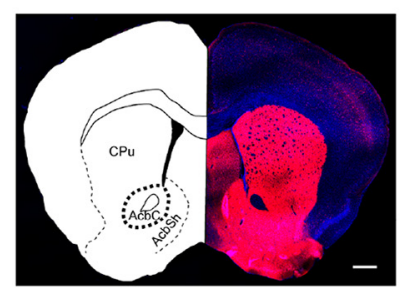

B

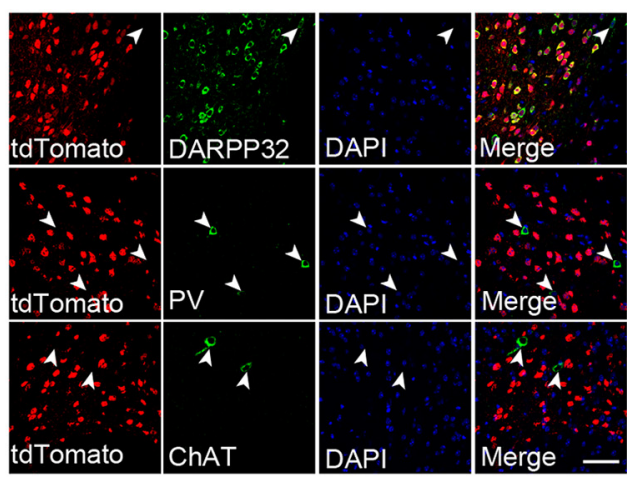

C

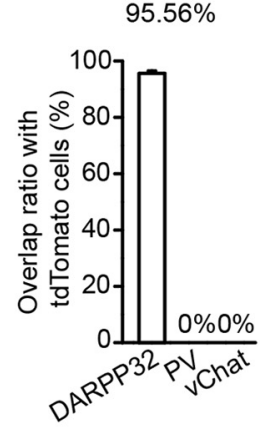

D
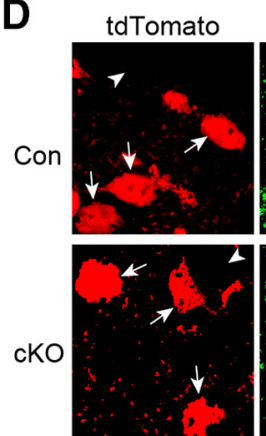
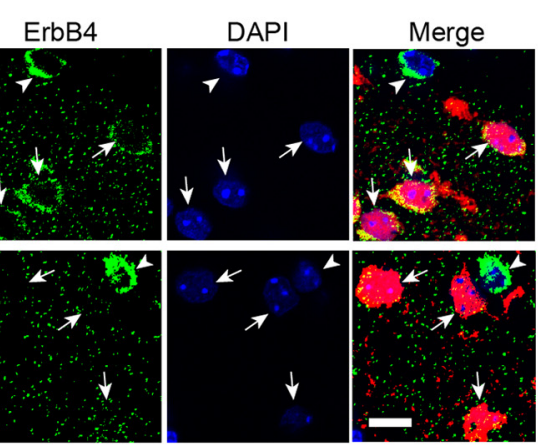

E

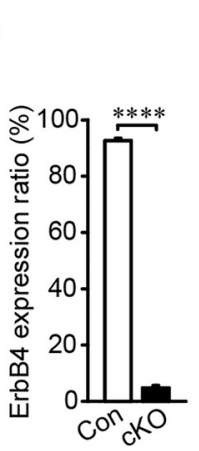

F

ErbB4

GAPDH

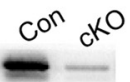

G

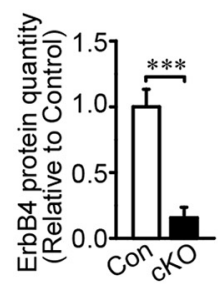

Figure 2. Erbb4 was deleted in the NAc core MSNs but not in PV-expressing or cholinergic interneurons in D/x5/6-cre; Erbb4 ${ }^{\text {loxp/loxp }}$ mice. $A$, Coronal section (AP $+1.18 \mathrm{~mm}$ ) of adult DIx5/6-cre;Ai9 reporter mice showing tdTomato-positive cells in the CPu and the NAc. Scale bar, $500 \mu \mathrm{m}$. Acbc, Core of NAc; AcbSh, shell of NAc. B, C, Neurons labeled in Dlx5/6-cre;Ai9 reporter mice were mostly MSNs but not PV-expressing ( $n=1325$ cells of 3 mice) or cholinergic interneurons ( $n=1626$ cells of 3 mice). Arrowheads, tdTomato-negative cells. Scale bar, $50 \mu \mathrm{m}$. $\boldsymbol{D}, \boldsymbol{E}$, Specific

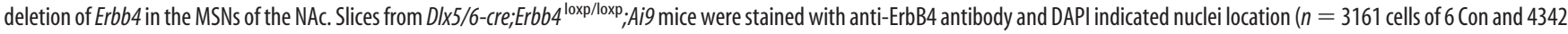
cells of 7 (KO). Arrows, MSNs; arrowheads, negative MSNs. Scale bar, $10 \mu \mathrm{m}$. $\boldsymbol{F}, \mathbf{G}$, Western blotting of the NAc proteins and quantification of ErbB4 in Con and cK0 mice ( $n=5)$. Statistical significance was determined by two-tailed $t$ test for unpaired data $(\boldsymbol{E}, \boldsymbol{G})$. All data are shown as mean $\pm \mathrm{SEM}$.

We further detected changes of mIPSCs after $\mathrm{GABA}_{\mathrm{A}} \mathrm{R} \alpha 1$ interference in the NAc core; 20 cells from five cKO-Scr mice and 22 cells from four cKO-shRNA mice were used for the mIPSC recording and statistical analysis was performed using the K-S $t$ test.

To explore the role of ErbB4 in the NAc core, we injected AAV-fDIOCre-EGFP virus to the NAc core in Dlx5/6-flp;Ai65 mice. A total of 428 cells from three AAV-fDIO-EGFP-transfected mice and 844 cells from four AAV-fDIO-Cre-EGFP-transfected mice were tested for the virus validity. By performing unpaired two-tailed $t$ test of fluorescent intensity of 1509 cells from three NAc-Con mice and 1854 cells from three NAccKO mice after DARPP32 staining, the viral transfection efficiency and reliability in the Con or cKO animals were verified.

To determine Erbb4 deletion and $\mathrm{GABA}_{\mathrm{A}} \mathrm{R} \alpha 1$ knock-down in the NAc core, 2395 cells from three NAc-Con mice and 2023 cells from four NAccKO mice were compared for ErbB4 immunostaining fluorescent intensity. Protein lysates from four NAc-Con mice and four NAc-cKO mice were immunoblotted for ErbB4 and $\mathrm{GABA}_{\mathrm{A}} \mathrm{R} \alpha 1$. Results of both immunostaining and immunoblotting were analyzed by unpaired two-tailed $t$ test. Eight cells from four NAc-Con mice and 50 cells from five NAc-cKO mice were used for $\mathrm{GABA}_{\mathrm{A}} \mathrm{R} \alpha 1$ immunostaining, followed by unpaired two-tailed $t$ test of staining intensity. Twenty-eight cells from four NAc-Con mice and 25 cells from three NAc-cKO mice were compared for mIPSCs by K-S $t$ test.

In testing behavior changes after precise Erbb4 deletion in the NAc core, behavior performance of $16 \mathrm{NAc}-\mathrm{Con}$ mice and $16 \mathrm{NAc}-\mathrm{cKO}$ mice was used for open-field analysis, 14 NAc-Con mice and $13 \mathrm{NAc}-\mathrm{cKO}$ mice for three chamber exploration analysis, and 15 NAc-Con mice and $15 \mathrm{NAc}-\mathrm{cKO}$ mice for PPI analysis and tested by two-way ANOVA with Bonferroni post hoc test. Fifteen NAc-Con mice and 15 NAc-cKO mice were used for marble-burying analysis and 14 NAc-Con mice and 13 NAc-cKO mice for three chamber preference analysis were analyzed by unpaired two-tailed $t$ test.

All data areexpressed as mean \pm SEM. Normal distribution was assessed by the Shapiro-Wilk statistical test. The null hypothesis, stating that the population is normally distributed, is accepted when $\alpha$ is determined as $\geq 0.05$. For all behavior tests, immunostaining, Western blot, and electrophysiology recording, only male mice were used. The sample size (mice/ slices/cells) was approved by power analysis using the $G^{*}$ power 3.1.9.2 and is listed for each experiment in the figure legends. All experiments were from at least three mice and the exact $p$-values are shown in the results. Statistical analyses were performed in Origin 8.0 software. Significance was determined and is reported as follows: ${ }^{*} p<0.05 ;^{* *} p<0.01$; $^{* * *} p<0.001$; $^{* * *} p<0.0001$.

\section{Results}

\section{Behavioral deficits in Erbb4 conditional mutants}

Dlx5/6-cre-transgenic mice express Cre recombinase in GABAergic forebrain neurons, including striatal MSNs (Zerucha et al., 2000). To confirm the Cre expression pattern, we crossed Dlx5/ 6-cre mice with the Ai9-tdTomato reporter line to detect the cre-positive neuron distribution. The direct striatonigral pathway could be detected distinctly in the sagittal section (Fig. 1A) and tdTomato-positive neurons were densely distributed in the forbrain areas such as the somatosensory cortex (Fig. 1B), striatum (Fig. 1C), hippocampus (Fig. 1D), and hypothalamus (Fig. $1 E)$. Furthermore, both dorsal striatum and ventral striatum had a td-Tomato-positive neuron distribution (Fig. $2 A$ ). To identify the neuronal subtypes of tdTomato-positive neurons in the striatum subregions the $\mathrm{CPu}$ and the NAc, we stained brain sections from Dlx5/6-cre;Ai9 mice for the MSN marker DARPP32, for PV, and for ChAT. tdTomato colocalized well with DARPP32, but not PV or ChAT in the CPu (Fig. $1 F$ ) and the NAc (Fig. $2 B, C$ ), suggesting that genetic ablation using $D l \times 5 / 6$-cre results in gene deletion in MSNs, but not in cholinergic neurons in the striatum.

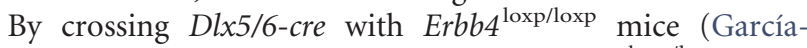
Rivello et al., 2005), we generated Dlx5/6-cre;Erbb4 $4^{\text {loxp/loxp }}$ ErbB4 


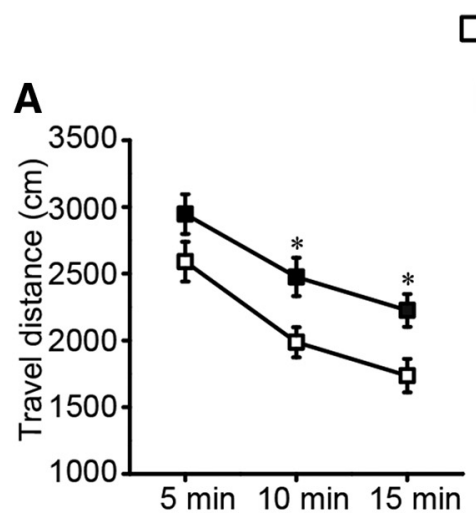

E

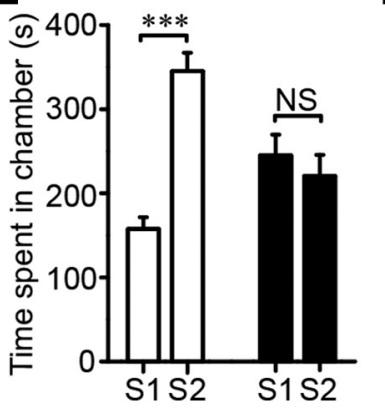

cKO
B

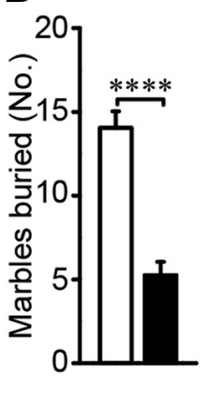

Con

$F$

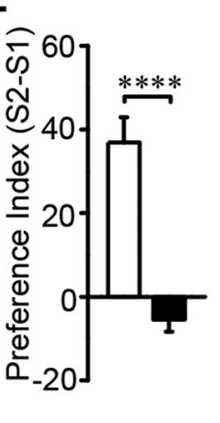

C
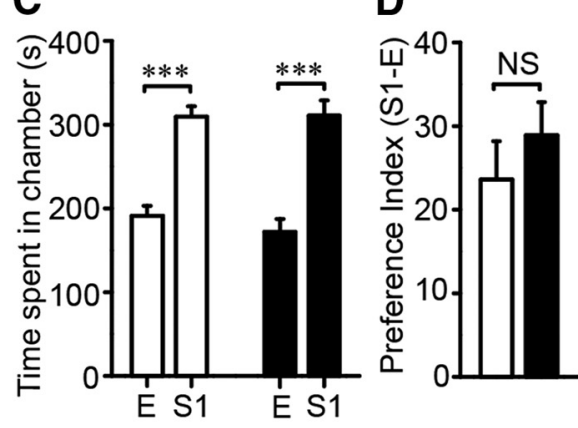

G

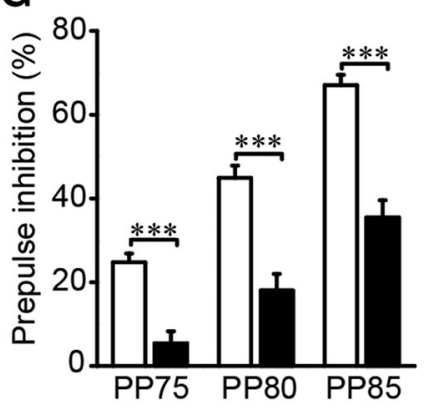

Figure 3. Erbb4 mutants showed schizophrenia-like behavioral deficits. $\boldsymbol{A}$, Erbb4 mutant mice showed increased locomoter activity in 15 min open-field test ( $n=16$ ). $\boldsymbol{B}$, Fewer marbles were buried by cKO mice, suggesting abnormal emotional behavior of the mice ( $n=15$ Con and 18 KKO). C, Similar to Con, cKO mice spent more time in the first stranger-containing chamber than the empty chamber, indicating normal social interaction of cKO mice. ( $n=13$ Con and 14 cKO). E, Empty chamber; S1, first stranger-containing chamber. $\boldsymbol{D}$, Con and cKO mice displayed similar preference to $\mathrm{S} 1$ ( $n=13$ Con and 14 CKO). $\boldsymbol{E}$, $\mathrm{KK}$ animals spent similar time in chambers having the first or second stranger, whereas the controls showed more interests to the latter, suggesting that cKO mice presented impaired social novelty recognition ( $n=13$ Con and $14 \mathrm{cKO}$ ). S2, Second stranger-containing chamber. $\boldsymbol{F}$, Erbb4 mutants showed less preference to $\mathbf{S 2}$ ( $n=13$ Con and 14 (KO). G, Decreased percentage of PPI indicating damaged sensorimotor gating function of cK0 animals ( $n=16$ Con and 15 cK0). Statistical significance was calculated by two-way repeatedmeasures ANOVA with Bonferroni post hoc test $(\boldsymbol{A}, \boldsymbol{C}, \boldsymbol{E}, \boldsymbol{G})$ or two-tailed $t$ test for unpaired data $(\boldsymbol{B}, \boldsymbol{D}, \boldsymbol{F})$. All data are shown as mean \pm SEM. NS, No significant difference.

cKO mice and littermate Erbb4 $4^{\text {loxp/loxp }}$ controls. Immunostaining showed that ErbB4 is abundantly expressed in MSNs in the $\mathrm{CPu}$ (Fig. 1G) and the NAc (Fig. 2D,E) in the controls, but is absent in MSNs of the $\mathrm{CPu}\left(t_{(6)}=5.367, p \ll 0.01\right.$; Fig. $\left.1 G\right)$ and the NAc $\left(t_{(11)}=70.944, p \ll 0.01\right.$; Fig. $\left.2 D, E\right)$ in the cKO mice. Western blotting of the NAc further confirmed that ErbB4 was knocked down in cKO mice $\left(t_{(8)}=5.415, p \ll 0.01\right.$; Fig. $\left.2 F, G\right)$.

To investigate the behaviors mediated by ErbB4 in striatal MSNs, we subjected these mice to a series of behavioral tests. cKO mice traveled for longer distances in 15 min open-field tests, indicating the presence of hyperactivity $\left(F_{(2,14)}=0.266, p=0.025\right.$ in the second 5 $\min , p=0.018$ in the third 5 min; Fig. $3 A$ ). The travel distance in the center was not different, indicating that hyperactivity was not dependent on anxiety level (data not shown). The elevated plus maze was also used to further evaluate anxiety behavior. We observed similar exploration times in both the open arms and the closed arms for the cKO and control groups (data not shown), suggesting that cKO mice did not exhibit anxiety-like behavior. cKO mice buried fewer marbles compared with controls in the marble-burying test $t_{(31)}=$ 6.954, $p \ll 0.01$; Fig. 3B).

To evaluate social or cognitive behavior changes in $\mathrm{CKO}$ mice, we subjected these mice to the three-chamber test and the PPI test. In the three-chamber social ability test, cKO mice displayed a normal social ability to identify their conspecifics $\left(F_{(1,25)}=\right.$ $1.518, p \ll 0.01$, Fig. $3 C$; $t_{(25)}=-0.828, p=0.427$, Fig. $\left.3 D\right)$, but failed to recognize a new arrival, indicating impaired social novelty recognition $\left(F_{(1,25)}=18.8, p \ll 0.01\right.$, Fig. $3 E$; $t_{(25)}=6.022$, $p \ll 0.01$, Fig. $3 F)$. We also measured sensorimotor gating function by analyzing the startle reflex in the PPI test. Although both groups responded similarly to the startle stimulus without a prepulse (data not shown), inhibition by prepulse stimulation was significantly lower in $\mathrm{cKO}$ mice, demonstrating impaired sensorimotor gating function $\left(F_{(2,27)}=1.943, p \ll 0.01\right.$; Fig. $\left.3 G\right)$.

\section{Loss of ErbB4 elevates $\mathrm{GABA}_{\mathrm{A}}$ receptor $\alpha 1$ expression, particularly in the striatum}

Erbb4 deletion in cortical areas compromises local GABAergic synaptic formation and transmission (Fazzari et al., 2010; Del Pino et al., 2013; Yang et al., 2013). To test whether Erbb4 deletion has a similar effect on striatal synaptic connections, we analyzed the expression of GABAergic and glutamatergic components in the striatum of 8- to 13-week-old mice. Surprisingly, $\mathrm{GABA}_{\mathrm{A}} \mathrm{R} \alpha 1$ expression was significantly increased in the striatum in the Erbb4 mutant mice $\left(t_{(8)}=-4.212, p \ll 0.01\right.$; Fig. $\left.4 A, B\right)$, whereas, in comparison, no significant differences in other $\mathrm{GABA}_{\mathrm{A}}$ receptor subunits, the $\alpha 2\left(t_{(5)}=0.134, p=0.866\right.$; Fig. $\left.4 A, B\right)$ and the $\beta 2$ $\left(t_{(4)}=-1.524, p=0.168\right.$; Fig. $\left.4 A, B\right)$ and the inhibitory postsynaptic protein gephyrin $\left(t_{(5)}=-1.021, p=0.46\right.$; Fig. $\left.4 C, D\right)$ or in the glutamatergic components GluN1 $\left(t_{(4)}=0.123, p=0.98\right.$; Fig. $4 C, D)$, GluNR2A $\left(t_{(4)}=-0.224, p=0.86\right.$; Fig. $\left.4 C, D\right)$ and GluNR2B $\left(t_{(4)}=0.766, p=0.14\right.$; Fig. $\left.4 C, D\right)$ were detected. Because Dlx5/6-cre mice had other forebrain area GABAergic interneurons labeled, we further wanted to confirm whether $\mathrm{GABA}_{\mathrm{A}} \mathrm{R} \alpha 1$ elevation had region specificity. The ErbB4 protein was did deleted in different forebrain areas such as the NAc $\left(t_{(8)}=5.415, p \ll 0.01\right.$; Fig. $\left.4 E, F\right)$, the $\mathrm{CPu}\left(t_{(4)}=4.142, p=\right.$ 0.014 ; Fig. $4 E, F)$, the prefrontal cortex $\left(t_{(4)}=3.623, p=0.022\right.$; Fig. $4 E, F)$, the hippocampus $\left(t_{(4)}=6.684, p \ll 0.01\right.$; Fig. $\left.4 E, F\right)$, 


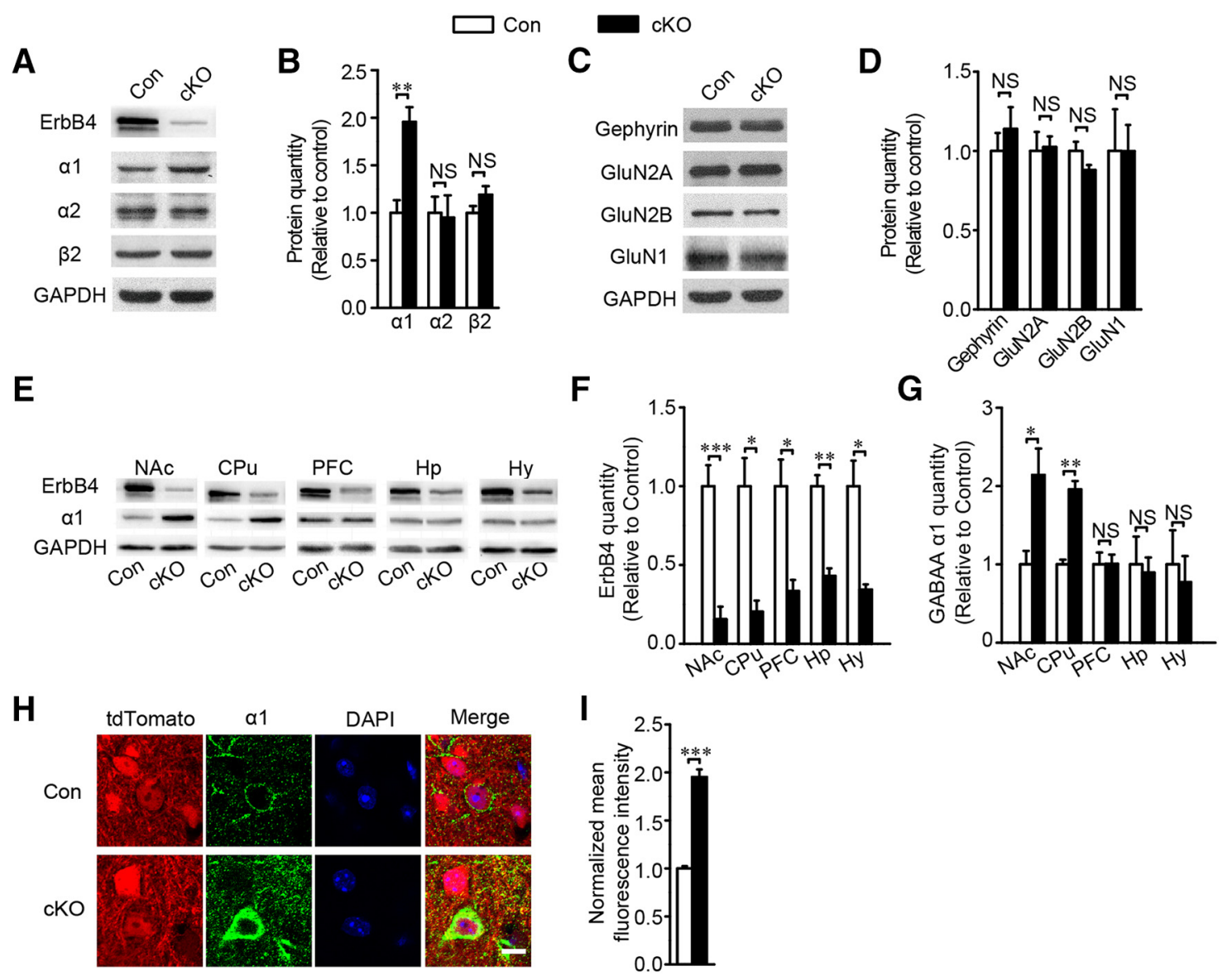

Figure 4. Loss of ErbB4 in striatum resulted in the upregulation of $G A B A_{A}$ receptor $\alpha 1$ subunit. $A, B, G A B A_{A} R \alpha 1$ was upregulated in the cK0 group with immunoblots and quantification of $G A B A_{A}$ receptor subunits $\alpha 1, \alpha 2$, and $\beta 2$ in the striatum of Con and cK0 mice (for $G A B A_{A} R \alpha 1, n=5$; for $G_{A B A} R \alpha 2, n=4$ Con and 3 cKO; for $G A B A_{A} R \beta 2, n=3$ ). $C, D$, Immunoblots and quantification of inhibitory postsynaptic protein gephyrin and excitatory postsynaptic proteins GluN2A, GluN2B, and GluN1 in cK0 striatum showing no change (for gephyrin, $n=4$ Con and 3 cKO; for GluN2A, GluN2B, GluN1, $n=3$ ), $\mathbf{E}-\mathbf{G}$, Immunoblots and statistical analysis of ErbB4 and $\mathrm{GABA}_{A} \mathrm{R} \alpha 1$ in positive areas tested in Erbb4 mutant mice including prefrontal cortex (PFC), hippocampus (Hp), hypothalamus (Hy), and striatum subregions the NAc and the CPu. GABA ${ }_{A} R \alpha 1$ was increased in the NAc and the CPu, but not in the PFC, Hp, or Hy (for NAc, $n=5$; for CPu, $n=3$; for PFC, $n=3$; for Hip, $n=3$; for thalamus, $n=5)$. $H$, I, Analysis of $G_{A B A} R \alpha 1$ fluorescence intensity showing increased expression in cK0 mice $(n=43$ cells of 4 Con and 51 cells of 5 cKO). Statistical significance was calculated with two-tailed $t$ test for unpaired data $(\boldsymbol{B}, \boldsymbol{D}, \boldsymbol{F}, \boldsymbol{G}, \boldsymbol{I})$. All data are shown as mean $\pm \mathrm{SEM}$. NS, No significant difference.

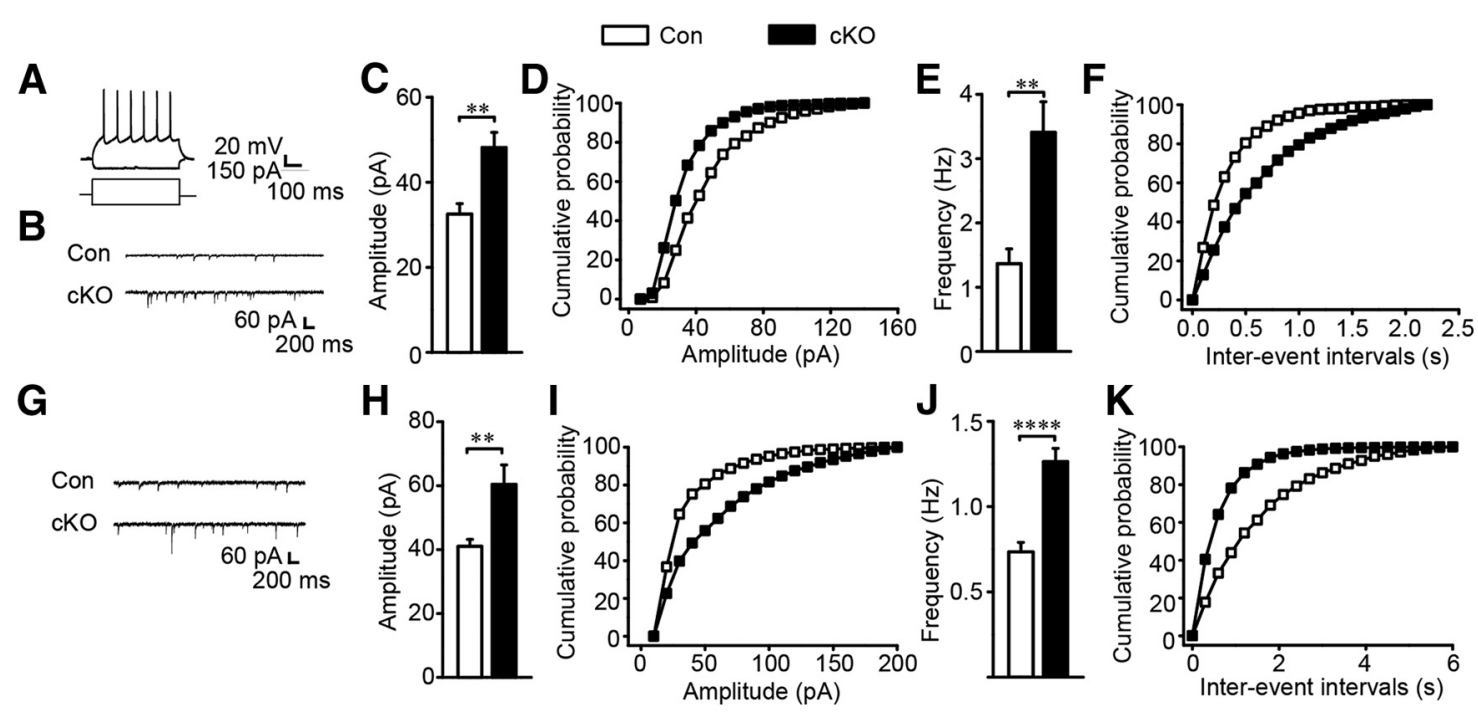

Figure 5. GABAergic synaptic transmission was increased in the CPu and NAc in Erbb4 mutant mice. $\boldsymbol{A}$, Representative action potentials of MSNs. $\boldsymbol{B}-\boldsymbol{F}$, Frequency and amplitude of mIPSC were increased in cKO mice with sample traces, histograms, and cumulative distribution plots in the CPu ( $n=15$ cells from 8 Con and 14 cells from 7 cKO) $\mathbf{G}-\boldsymbol{K}$, mIPSC frequency and amplitude were increased in the NAc of $\mathrm{CKO}$ mice ( $n=18$ cells from 5 Con and 22 cells from $5 \mathrm{cKO})$. Statistical significance was calculated using K-St test $(\boldsymbol{C}, \boldsymbol{E}, \boldsymbol{H}, \boldsymbol{J})$. All data are shown as mean \pm SEM. 

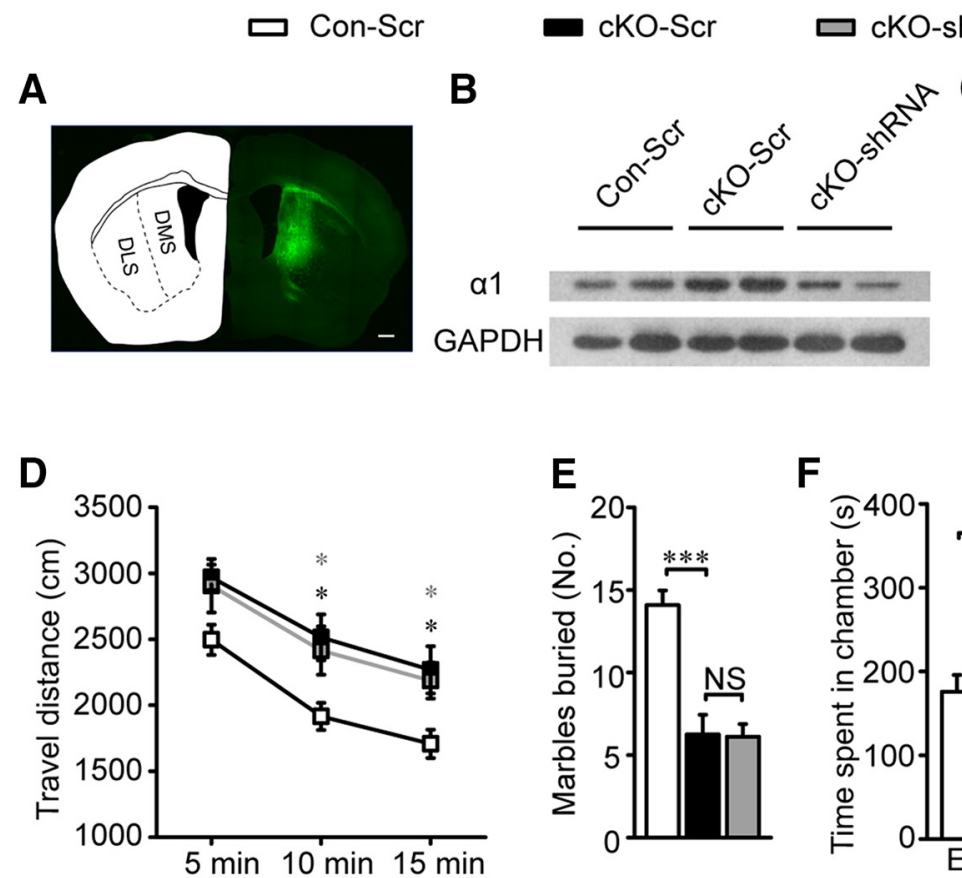

F
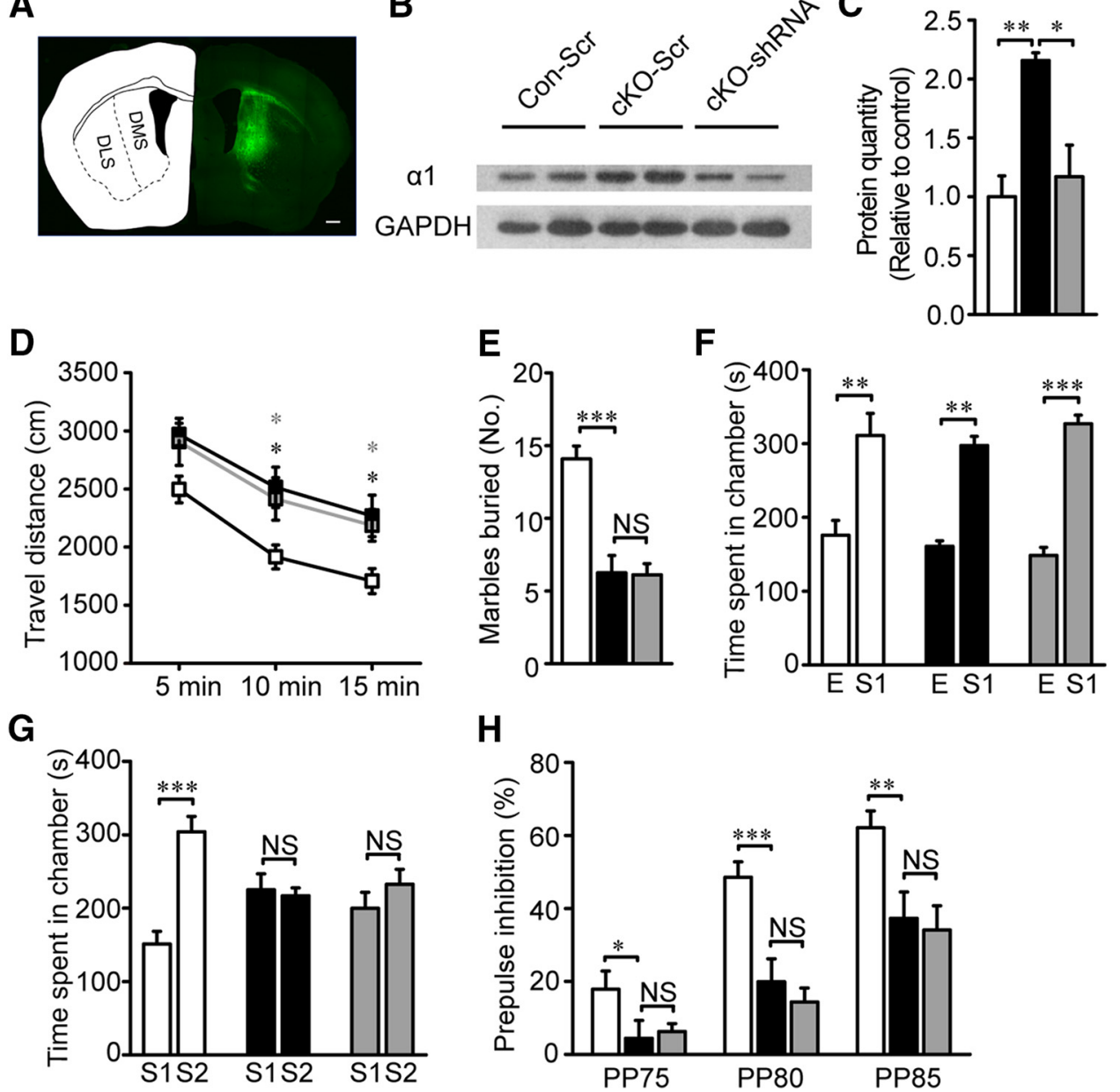

Figure 6. Restoring GABA function specifically in DMS did not rescue behavior deficits. $A$, GFP expression in cells 3 weeks after virus transfection to DMS (AP $+0.5 \mathrm{~mm}, \mathrm{ML} \pm 1.9 \mathrm{~mm}$ and DV + $3.2 \mathrm{~mm}$ ). Scale bar, $500 \mu \mathrm{m}$. B, C, Representative immunoblots and quantification of GABA $\mathrm{A} \alpha \alpha 1$ in the CPu of Con-Scr, cKO-Scr, and cKO-shRNA mice ( $n=3$ Con-Scr, 3 cKO-Scr, and 3 cK0-shRNA). D, Hyperactivity was almost not changed during open-field test in cKO mice after interfering GABA $\mathrm{R} \alpha 1$ expression in DMS ( $n=12$ Con-Scr, 12 cKO-Scr, and 10 cKO-shRNA). $E$, Almost equal buried marbles were counted between cKO-Scr and cKO-shRNA ( $n=12$ Con-Scr, $8 \mathrm{cKO}$-Scr, and $9 \mathrm{cKO}$-shRNA). $\boldsymbol{F}$, Virus injection did not have any effect on social interaction behavior ( $n=12$ Con-Scr, 8 cKO-Scr, and 9 CKO-shRNA). G, Impaired social novelty recognition did not reverse during three chamber test after restoring GABA function in DMS because both cKO-Scr and cKO-shRNA showed no preference between first and second stranger ( $n=12$ Con-Scr, $8 \mathrm{cKO}$-Scr, and $9 \mathrm{cKO}$-shRNA). $\boldsymbol{H}$, Similar percentage of PPI between cK0-Scr and cK0-shRNA demonstrated interfering GABA ${ }_{A} R(1$ expression in DMS did not restore sensorimotor gating function ( $n=12 \mathrm{Con}-\mathrm{Scr}, 8 \mathrm{cKO}$-Scr, and $9 \mathrm{cKO}$-shRNA). In the behavior test of the DMS virus injection, the virus expression in one cKO-shRNA mice was not restricted to the DMS and its data were excluded for the behavior analysis. Statistical significance was determined by one-way ANOVA with Bonferroni post hoc test ( $\boldsymbol{C}, \boldsymbol{E}$ ) or two-way ANOVA with Bonferroni post hoc test $(\boldsymbol{D}, \boldsymbol{F}, \boldsymbol{G}, \boldsymbol{H})$. All data are shown as mean \pm SEM. NS, No significant difference.

and the hypothalamus $\left(t_{(4)}=3.96, p=0.017\right.$; Fig. $\left.4 E, F\right)$. However, $\mathrm{GABA}_{\mathrm{A}} \mathrm{R} \alpha 1$ increase was just detected in the striatum subregions including the NAc $\left(t_{(8)}=-3.029, p=0.016\right.$; Fig. $\left.4 E, G\right)$ and the $\mathrm{CPu}\left(t_{(4)}=-7.814, p \ll 0.01\right.$; Fig. $\left.4 E, G\right)$, not in other forebrain regions, including the prefrontal cortex $\left(t_{(4)}=-0.033\right.$, $p=0.975$; Fig. $4 E, G)$, the hippocampus $\left(t_{(4)}=0.262, p=0.807\right.$; Fig. $4 E, G)$, and the hypothalamus $\left(t_{(4)}=0.416, p=0.699\right.$; Fig. $4 E, G)$. Western blotting results were corroborated by immunostaining of brain slices for $\mathrm{GABA}_{\mathrm{A}} \mathrm{R} \alpha 1$ in the striatum, which showed higher fluorescence intensity in the cKO group $\left(t_{(7)}=\right.$ $-10.34, p \ll 0.01$; Fig. $4 H, I)$.

As a critical component of GABA receptors, GABA $_{\mathrm{A}} \mathrm{R} \alpha 1$ closely participates in GABAergic synaptic transmission (Okada et al., 2000; Vicini et al., 2001). To investigate whether the upregulation of $\mathrm{GABA}_{\mathrm{A}} \mathrm{R} \alpha 1$ altered striatal GABAergic synaptic transmission, we prepared acute brain slices and performed whole-cell recordings in the NAc and the $\mathrm{CPu}$. The identified action potentials and the mIPSC traces of MSNs in the CPu and
NAc were shown in Figure 5, $A, B$, and $G$. Interestingly, both the amplitude and frequency of the mIPSCs in MSNs in the CPu $\left(t_{(27)}=\right.$ $-2.132, p \ll 0.01$, Fig. $5 C, D ; t_{(27)}=-2.253, p \ll 0.01$, Fig. $5 E, F)$ and the NAc $\left(t_{(38)}=-2.739, p \ll 0.0\right.$, Fig. $5 H, I ; t_{(38)}=$ $-5.254, p \ll 0.01$, Fig. $5 \mathrm{~J}, K)$ of $\mathrm{cKO}$ mice were significantly increased compared with the controls. In contrast, the amplitude and frequency of the miniature EPSC (mEPSC) were similar between control and cKO mice (data not shown). These results indicate that the loss of ErbB4 in striatal MSNs specifically enhances GABAergic but not glutamatergic synaptic transmission.

\section{Knock-down of $\mathrm{GABA}_{\mathrm{A}} \mathrm{R} \boldsymbol{\alpha} 1$ in the NAc core but not the} dorsomedial striatum restores behavior performance The NAc core and the DMS have been implicated in cognition and motivation behavior (Cardinal et al., 2001; Yin et al., 2005; Balleine et al., 2007; Mai et al., 2015). Dysfunction of the NAc core leads to impulsive choice, whereas damage to the two afferents, the anterior cingulate cortex and the medial prefrontal cor- 


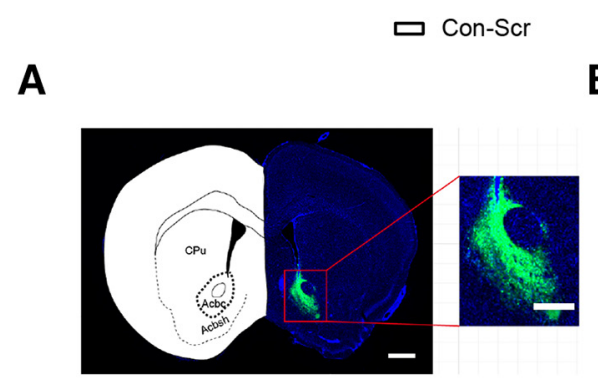

cKO-shRNA
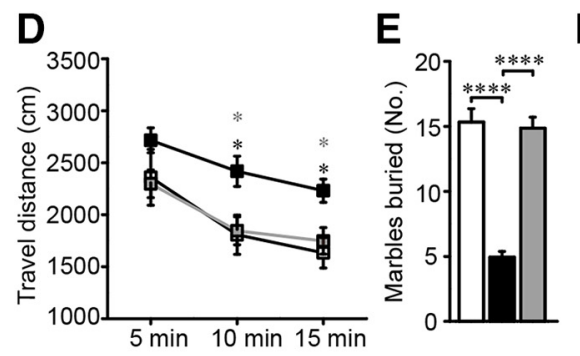

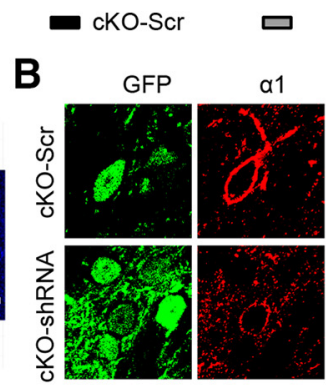

$F$
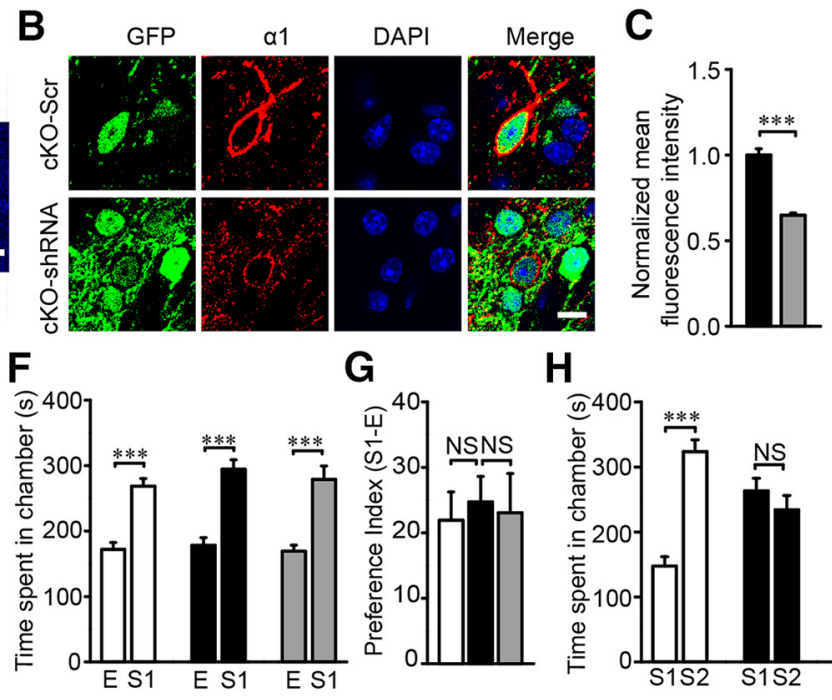

G

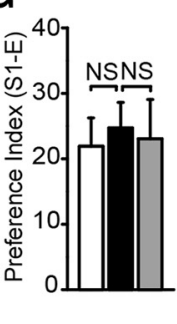

$\mathbf{H}$

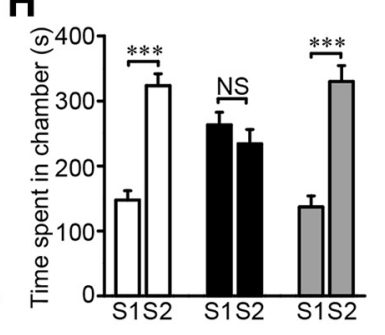

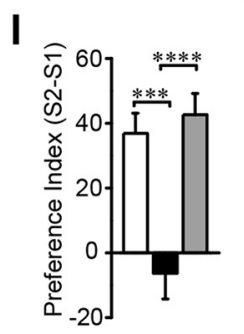

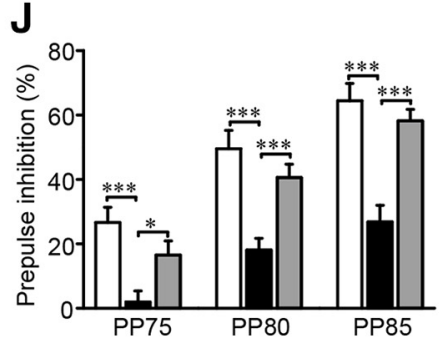

Figure 7. Knocking down $\mathrm{GABA}_{\mathrm{A}} \mathrm{R} \alpha 1$ specifically in the NAc core of cKO mice rescued animal behavior deficits. $A$, Neurons infected by virus distribution in the core of NAc (AP $+1.34 \mathrm{~mm}, \mathrm{ML} \pm$ $0.8 \mathrm{~mm}$, and DV $+4.6 \mathrm{~mm}$ ) three weeks after injection. Left image, Scale bar, $1000 \mu \mathrm{m}$; right image, scale bar, $500 \mu \mathrm{m} . B, C, G A B A_{A} R \alpha 1$ expression was restored to a nearly normal level after injecting interference virus with normalized mean fluorescence intensity ( $n=24$ cells from 4 nonrescues and 50 cells from 4 rescues). Scale bar, $5 \mu \mathrm{m}$. $D$, Hyperactivity in open-field test was rescued to normal after interfering with $\alpha 1$ expression ( $n=8 \mathrm{Con}-\mathrm{Scr}, 14 \mathrm{CKO}-\mathrm{Scr}, 12 \mathrm{CKO}$-shRNA). Black star, Comparison between Con-Scr and cK0-Scr; gray star, comparison between cK0-Scr and cK0-shRNA. $\boldsymbol{E}$, Marbles buried by cKO mice after $\mathrm{GABA}_{\mathrm{A}} \mathrm{R} \alpha 1$ interference were comparable to the controls ( $n=12$ Con-Scr, 15 cKO-Scr, 14 cKO-shRNA). $\boldsymbol{F}$, $\mathbf{G}$, cK0-shRNA mice showed normal interests to $S 1$ in three chamber test ( $n=11$ Con-Scr, 12 cKO-Scr, 13 CKO-shRNA). $\boldsymbol{H}, \mathbf{I}$, cK0-shRNA mice regained interests to $S 2$, suggesting restored social novelty recognition after reducing $\alpha 1$ expression ( $n=11$ Con-Scr, 12 cKO-Scr, 13 cKO-ShRNA). J, Normalized percentage of PPI in cK0 mice after NAc core $\alpha 1$ interference implying restored sensorimotor gating function ( $n=10$ Con-Scr, 14 CKO-Scr, 14 CKO-shRNA). In this behavior test of the NAc core virus injection, the virus expression in one Con-Scr mouse and one cKO-Scr mouse was not limited to the NAc core and their data were excluded for all the behavior analysis. Statistical significance was determined by two-tailed $t$ test for unpaired data (C), two-way ANOVA with Bonferroni post hoc test $(\boldsymbol{D}, \boldsymbol{F}, \boldsymbol{H}, \boldsymbol{J})$, or one-way ANOVA with Bonferroni post hoc test $(\boldsymbol{E}, \boldsymbol{G}, \boldsymbol{I})$. All data are shown as mean \pm SEM. NS, No significant difference.

tex, had no effect on this capacity (Cardinal et al., 2001). The DMS is preferentially recruited during skill learning compared with the DLS (Yin et al., 2009). Inspired by these studies, we further examined whether the NAc core and/or the DMS were involved in these abnormal behaviors of ErbB4 mutants.

To test whether elevated $\mathrm{GABA}_{\mathrm{A}} \mathrm{R} \alpha 1$ expression causes these behavior deficits, we bilaterally injected virus expressing $\mathrm{GABA}_{\mathrm{A}} \mathrm{R} \alpha 1$ short hairpin RNA (shRNA) along with GFP (AAV- $\alpha 1$-shRNAGFP) to specifically knock down $\mathrm{GABA}_{\mathrm{A}} \mathrm{R} \alpha 1$ in the DMS (Fig. $6 A$ ) or the NAc core (Fig. 7A) in cKO mice. Animals that received viruses expressing scrambled shRNA with GFP (AAV-scrambleGFP) served as controls (Con-Scr, Con mice with scrambled shRNA virus; $\mathrm{CKO}-\mathrm{Scr}, \mathrm{cKO}$ mice with scrambled shRNA virus). Three weeks after virus injection, we validated the knock-down efficiency in the injected animals and performed a series of behavioral, immunohistochemical, Western blot's and electrophysiological assays. To exclude the possible interference of off-target viral injection on behavioral performance, mice which finished behavioral tests first were perfused, fixed, and checked for GFP fluorescence in the targeted region after brain tissue sections were prepared. Behavioral data from those with GFP fluorescence beyond the targeted regions were excluded from statistical analysis of behavioral results. For immunohistochemical and electro- physiological analysis, brain sections were prepared and viral injection accuracy was confirmed before any following assays. For Western blot experiments, the potential off-target effect was minimized by three factors: 1 ) only tissues from targeted regions were collected; 2) chances of off-target viral infection were equal among all groups; 3 ) each group have multiple replicates. Overall, our transfection efficiency and virus reliability exceeded $80 \%$ (data not shown). $\mathrm{GABA}_{\mathrm{A}} \mathrm{R} \alpha 1$ expression was significantly decreased in the DMS $\left(F_{(2,6)}=10.82, p=0.01\right.$; Fig. $\left.6 B, C\right)$ and the NAc core $\left(t_{(6)}=8.915, p \ll 0.01\right.$; Fig. $\left.7 B, C\right)$ of AAV- $\alpha 1$-shRNAGFP-infected mice.

In the cKO-shRNA mice in the DMS, we detected no effect on open-field test $\left(F_{(2,32)}=0.123, p=0.974\right.$; Fig. $\left.6 D\right)$, marbleburying test $\left(F_{(2,26)}=25.38, p=0.923\right.$; Fig. $\left.6 E\right)$, three chamber test $\left(F_{(2,27)}=0.104, p=0.532\right.$, Fig. $6 F ; F_{(2,27)}=0.82, p=0.45$, Fig. $6 G)$, or PPI test $\left(F_{(2,27)}=0.673, p=0.519\right.$; Fig. $\left.6 H\right)$. In contrast to the failure of behavior rescue by $\mathrm{GABA}_{\mathrm{A}} \mathrm{R} \alpha 1$ shRNA in the DMS, GABA $\mathrm{R} \alpha 1$ knock-down in the NAc core of cKO mice showed a marked difference. Hyperactivity $\left(F_{(2,31)}=5.359\right.$, $p=0.014$; Fig. $7 D)$, aberrant marble-burying performance $\left(F_{(2,38)}=59.441, p \ll 0.01\right.$; Fig. $\left.7 E\right)$, social novelty recognition deficits $\left(F_{(2,33)}=0.251, p=0.779\right.$, Fig. $7 F ; F_{(2,33)}=10.35, p \ll$ 0.01 , Fig. $7 G ; F_{(2,33)}=0.875, p=0.426$, Fig. $7 H ; F_{(2,33)}=8.015$, 


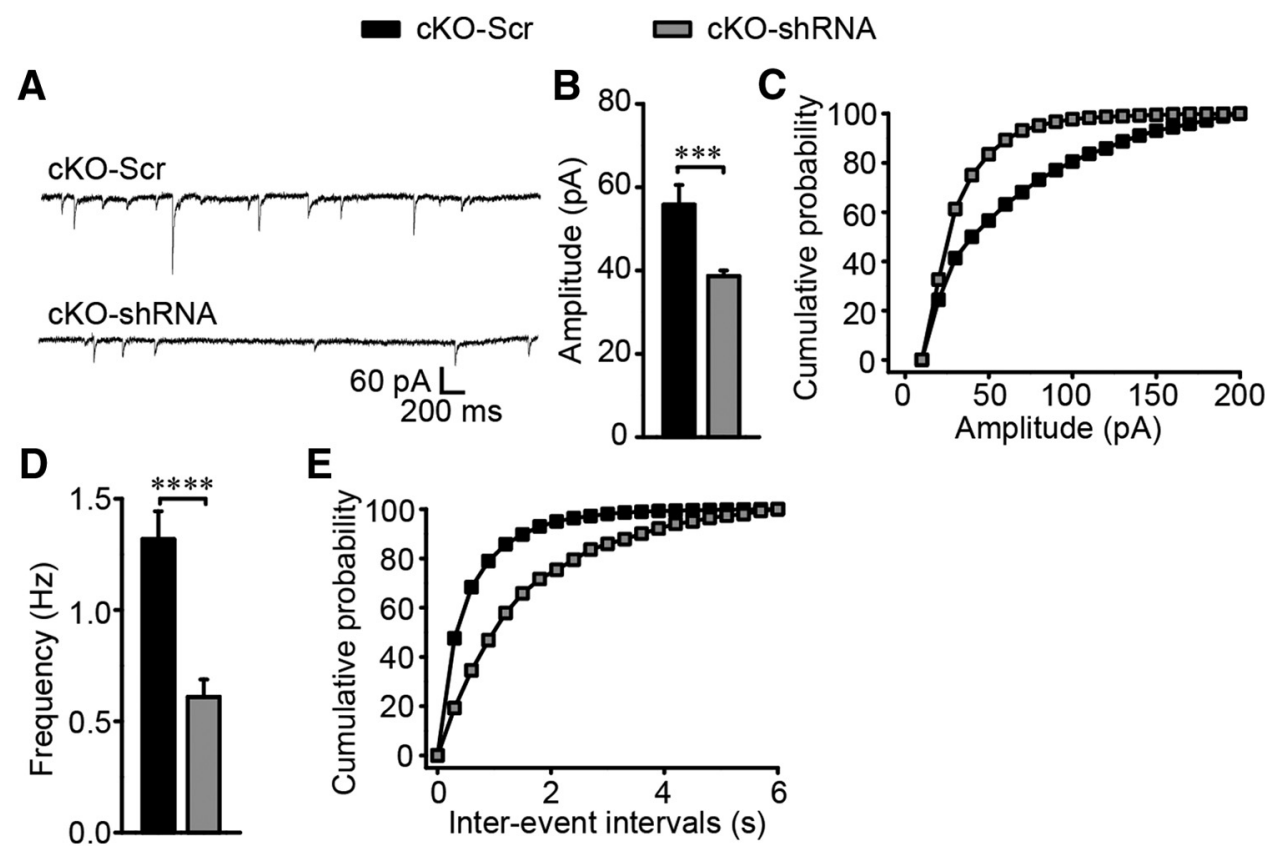

Figure 8. Restored inhibitory transmission in the NAc core after $\alpha 1$ expression interference. $A$, Sample traces of mIPSC in the NAc core of cK0 mice after GABA $R \alpha 1$ expression interference in the same region. $\boldsymbol{B}-\boldsymbol{E}$, $\mathrm{mIPSC}$ frequency and amplitude were restored to normal levels in cK0-shRNA mice with histograms and cumulative distribution plots ( $n=20$ cells from 5 nonrescues and 22 cells from 4 rescues). In this experiment, all virus expression was restricted to the NAc core, so all the data were included in the mIPSC analysis. Statistical significance was calculated using K-St test (B, $\boldsymbol{D}$ ). All data are shown as mean \pm SEM.

$p \ll 0.01$, Fig. $7 I)$, and inadequate PPI $\left(F_{(2,35)}=35.27, p \ll\right.$ 0.01 ; Fig. $7 \mathrm{~J})$ were all rescued compared with $\mathrm{cKO}$ mice infected with viruses expressing scramble shRNA. These results indicate that the change in the NAc core is the primary cause of those behavioral deficits in ErbB4 mutants.

The synaptic transmission was further detected in the NAc core MSNs after $\mathrm{GABA}_{\mathrm{A}} \mathrm{R} \alpha 1$ expression disturbance and the representative mIPSC traces are presented in Figure $8 A$. Similar to behavioral rescue, knocking down $\mathrm{GABA}_{\mathrm{A}} \mathrm{R} \alpha 1$ in the NAc core of $\mathrm{cKO}$ mice restored the amplitude $\left(t_{(40)}=4.87, p \ll 0.01\right.$; Fig. $8 B, C)$ and frequency $\left(t_{(6)}=3.635, p \ll 0.01\right.$; Fig. $\left.8 D, E\right)$ of mIPSCs to control levels.

\section{Local Erbb4 deletion in the NAc core MSNs caused GABA $A_{A}$ $\alpha 1$ overexpression and behavior deficits}

We showed above that $\mathrm{GABA}_{\mathrm{A}} \mathrm{R} \alpha 1$ overexpression in the NAc core is necessary for these behavioral abnormalities of Erbb4-deficient mice in which gene deletion was driven by $\mathrm{Dl} x 5 / 6-\mathrm{Cre}$. As shown in Figure 1, Cre recombinase is expressed in other forebrain regions aside from the striatum. $\mathrm{GABA}_{\mathrm{A}} \mathrm{R} \alpha 1$ overexpression in the NAc core could therefore be secondary to alter synaptic input from other Erbb4-deficient regions projecting to the NAc or could be due to local Erbb4 deletion in the NAc core MSNs.

To test whether Erbb4 deletion in the NAc core was sufficient to induce these abnormal behaviors, we combined Flp- and Cremediated genetic modification to achieve precise Erbb4 deletion in the MSNs of the NAc core and then evaluated animal behavior. We generated Dlx5/6-flp;Erbb4 ${ }^{\text {loxp/loxp }}$ mice by crossing Dlx5/6$f l p$ mice (Miyoshi et al., 2010) with Erbb4 ${ }^{\text {loxp/loxp }}$ mice and then stereotactically injecting virus expressing Flp-dependent Cre recombinase (AAV-fDIO-Cre-GFP) into the NAc core of these mice so that Erbb4 could be specifically deleted in the MSNs of the NAc core (NAc-cKO). Dlx5/6-flp;Erbb4 $4^{\text {loxp/loxp }}$ mice injected with control virus expressing only GFP (AAV-fDIO-GFP) served as controls (NAc-Con).
To confirm whether viral AAV-fDIO-Cre-GFP was Flp dependent and initiated Cre recombinase expression, we injected the virus into the Dlx5/6-flp;Ai65 mice in which tdTomato can be activated only when both Cre and Flp recombinase are expressed in the same neuron (Madisen et al., 2015). We detected that the Dlx5/6-flp;Ai65 mice injected with AAV-fDIO-Cre-GFP showed a 90.11\% overlap of GFP and tdTomato, whereas AAV-fDIO-GFP did not induce tdTomato expression, indicating the Flp-dependent expression of Cre recombinase in AAV-fDIO-Cre-GFP transfected cells (Fig. $9 A, B$ ) and the virus transfection efficiency was considered to be reliable $\left(t_{(4)}=-0.236, p=0.825\right.$; Fig. $\left.9 C, D\right)$.

To ensure that the virus injection was limited to the NAc core, we checked GFP fluorescence in the brain slices 3 weeks after virus was injected into the Dlx5/6-flp;Erbb4 $4^{\text {loxp/loxp }}$ mice. As expected, the virus expression in most mice was restricted to the NAc core (Fig. 9E). Mice with off-target virus infusion were excluded in all statistical analysis. In the NAc-cKO mice, both immunostaining $\left(t_{(5)}=70.944, p \ll 0.01\right.$; Fig. $\left.10 \mathrm{~A}, B\right)$ and Western blotting $\left(t_{(6)}=5.94, p \ll 0.01\right.$; Fig. $\left.10 C, D\right)$ confirmed that ErbB4 was successfully knocked out in the NAc core MSNs. In addition, the elevated expression of $\mathrm{GABA}_{\mathrm{A}} \mathrm{R} \alpha{ }_{\left(t_{(6)}\right.}=-3.667, p=$ 0.0104 , Fig. $10 C, D ; t_{(6)}=-4.085, p \ll 0.01$, Fig. $\left.10 E, F\right)$ and the increased amplitude $\left(t_{(51)}=-3.342, p \ll 0.01\right.$; Fig. $\left.10 G-I\right)$ and frequency $\left(t_{(51)}=-3.285, p \ll 0.01\right.$; Fig. $\left.10 G, J, K\right)$ of mIPSCs were recapitulated in the NAc-cKO mice. Furthermore, NAc-cKO mice also displayed increased locomotion $\left(F_{(2,30)}=3.216, p=0.047\right.$; Fig. 11A), reduced marble-burying behavior $\left(t_{(28)}=19.353, p \ll\right.$ 0.01 ; Fig. $11 B)$, and normal sociability $\left(F_{(2,25)}=0.0037, p=0.952\right.$, Fig. $11 C ; t_{(25)}=-0.219, p=0.828$, Fig. $\left.11 D\right)$, but abnormal social novelty recognition $\left(F_{(2,25)}=70.79, p \ll 0.01\right.$, Fig. $11 E$; $t_{(25)}=$ 7.144, $p \ll 0.01$, Fig. $11 F)$ and decreased PPI $\left(F_{(2,27)}=1.022, p=\right.$ 0.021 , PP75; $p \ll 0.01$, PP80; $p \ll 0.01$, PP85; Fig. $11 G)$. In summary, precisely deleting Erbb4 in the NAc core MSNs recapitulated all phenotypes presented by previous $\mathrm{CKO}$ mice. 
A

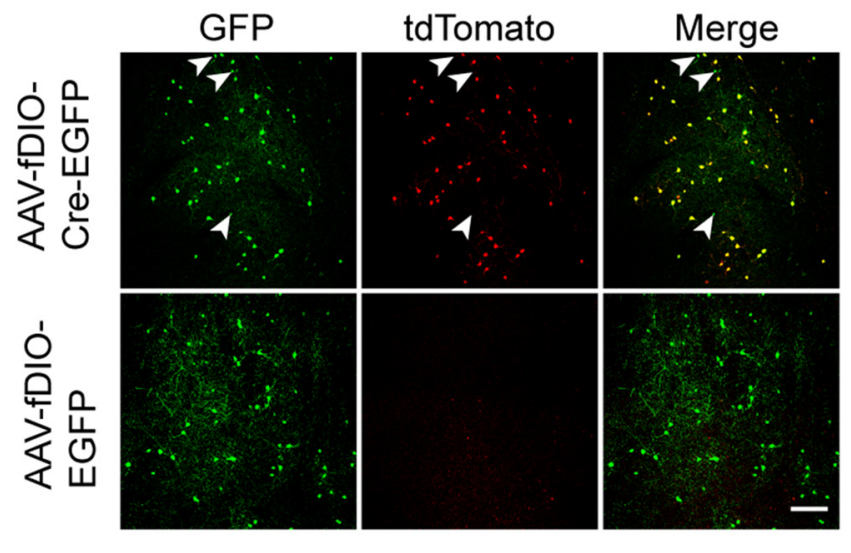

C
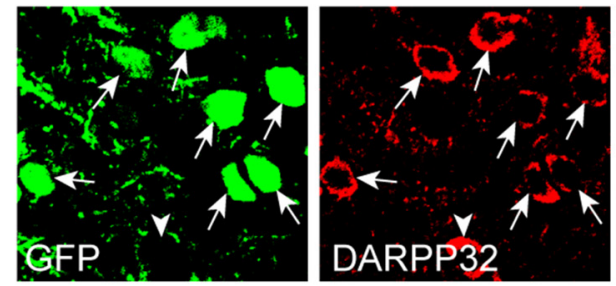

D

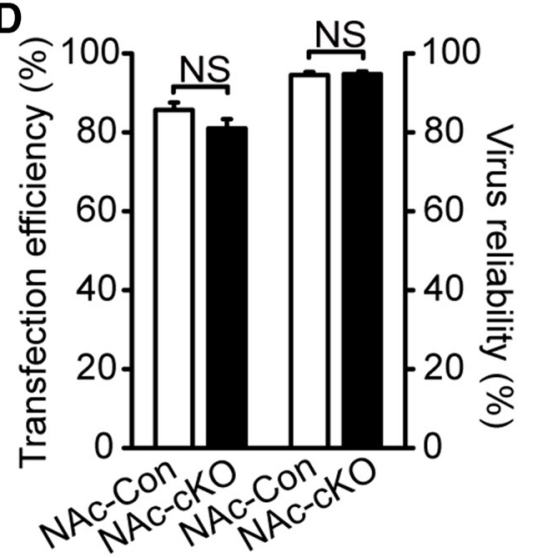

B

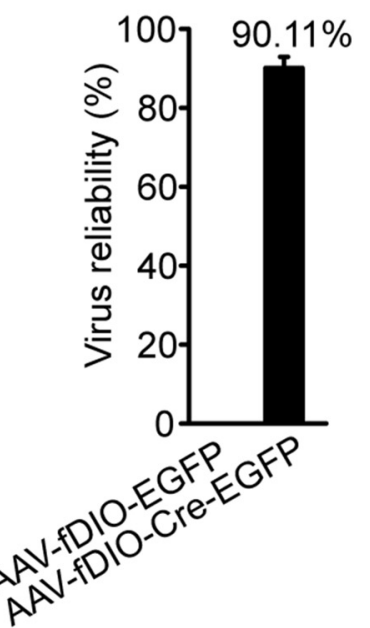

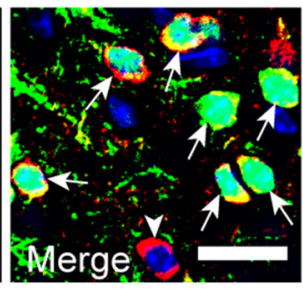

E

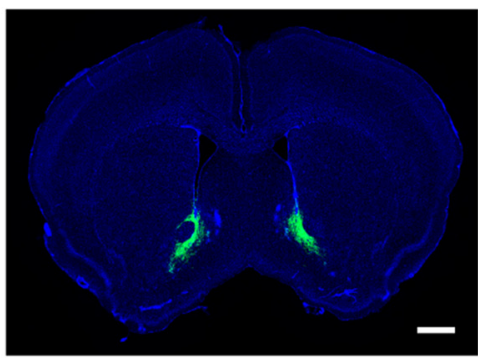

Figure 9. AAV-fDIO-Cre-EGFP virus could induce cre recombinase expression in a flp depended manner with high efficiency and reliability. $A, B$, AAV-fDIO-Cre-EGFP virus successfully induced tdTomato expression in Dlx5/6-flp;Ai65 mice after injected into the NAc core (AP $+1.34 \mathrm{~mm}, \mathrm{ML} \pm 0.8 \mathrm{~mm}$ and DV $+4.6 \mathrm{~mm}$ ) and histograms of statistical results are shown $(n=428$ cells of 3 AAV-fDI0-EGFP virus transfected mice and 844 cells of 4 AAV-fDI0-Cre-EGFP virus transfected mice). Arrowheads pointed to few tdTomato-negative neurons and GFP-positive neurons. Scale bar, 100 $\mu \mathrm{m} . C, D, D A R P P 32$ in MSNs in virus transfected brain slices stained with DAPI indicating nuclei location and histograms of transfection efficiency and virus reliability $(n=1509$ cells from 3 NAc-Con and 1854 cells from 3 NAc-cKO). Scale bar, $20 \mu \mathrm{m}$. E, Representative virus expression in the core of NAc (AP $+1.34 \mathrm{~mm}, \mathrm{ML} \pm 0.8 \mathrm{~mm}$ and DV $+4.6 \mathrm{~mm}$ ) 3 weeks after injection. Scale bar, 1000 $\mu \mathrm{m}$. In this experiment, all virus expression was restricted to the NAc core, so all data are included in the virus reliability analysis. Statistical significance was determined by two-tailed $t$ test for unpaired data (D). All data are shown as mean \pm SEM. NS, No significant difference.

\section{Discussion}

Here, we found that the loss of ErbB4 in the striatum, specifically in the NAc core, led to hyperactivity in the open-field test, impaired marble-burying behavior, damaged social novelty recognition in the social ability test, and dysfunctional startle reflex in the PPI test. All of these abnormal behaviors raised the possibility that the striatal ErbB4 mutants presented schizophrenia-like behaviors similar to what was observed in other schizophrenia-like mice models in previous reports (Belforte et al., 2010; Del Pino et al., 2013; Park et al., 2015). Erbb4 deletion induced upregulated $\mathrm{GABA}_{\mathrm{A}} \mathrm{R} \alpha 1$ expression and hyperactive GABAergic synaptic transmission in the striatum. Remarkably, all abnormal behav- iors could be rescued by interfering with $\mathrm{GABA}_{\mathrm{A}} \mathrm{R} \alpha 1$ expression in the NAc core. These results highlight the role of ErbB4 in $\mathrm{GABA}_{\mathrm{A}}$ receptor function in the NAc core and suggest a new molecular mechanism for striatal MSNs in cognitive and social impairments of neuropsychiatric diseases.

ErbB4 in the NAc, but not other striatal subregions, contributes to schizophrenia-like behaviors

Genome-wide analysis of clinical specimens detected various ErbB4 mutations. For instance, ErbB4 kinase domain is partially deleted in one set of schizophrenic patients (Walsh et al., 2008). Biochemical analysis of brain tissues from schizophrenic patients 


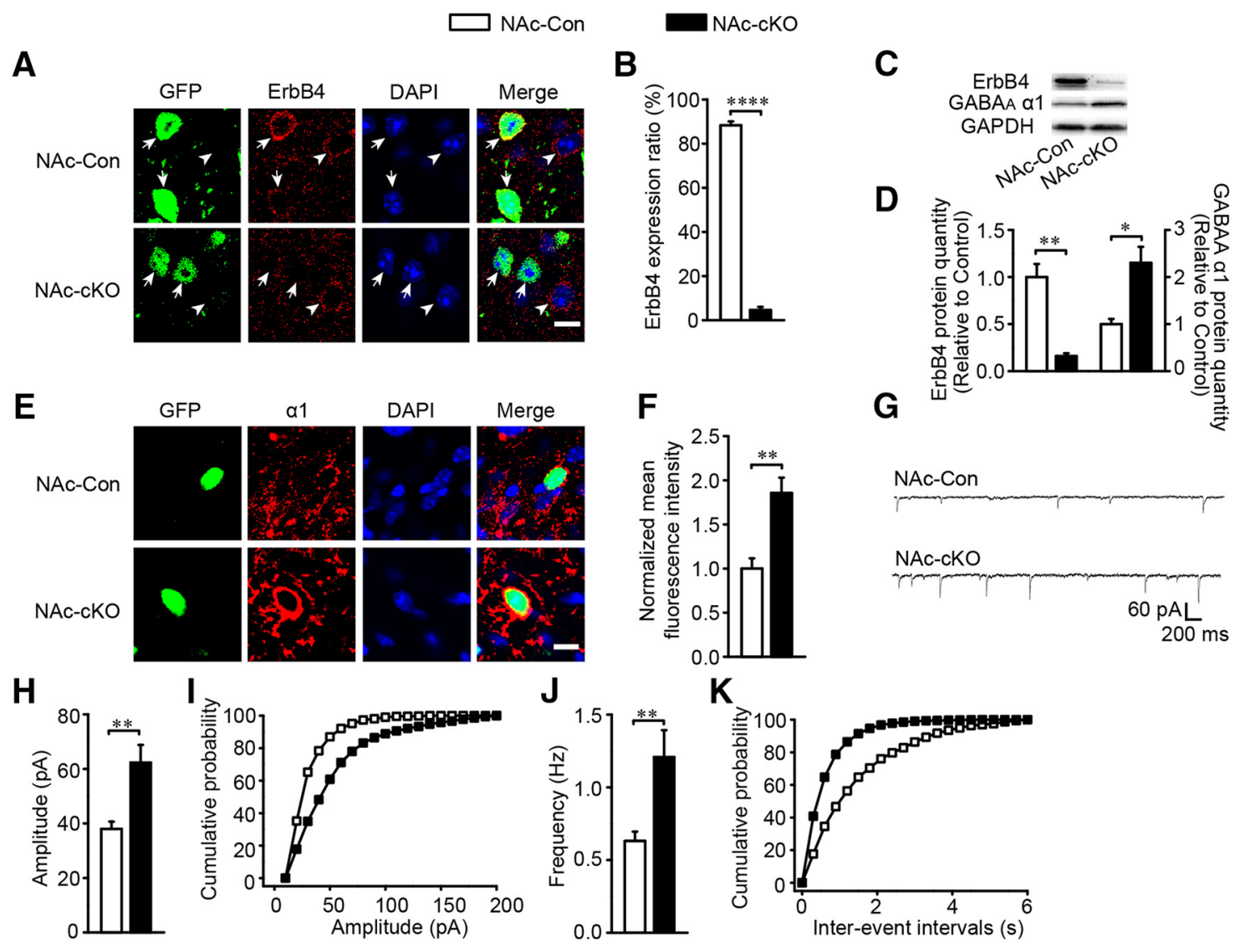

Figure 10. Precise Erbb4 deletion in the NAccore MSNs increased inhibitory transmission and $G A B A_{A} R \alpha 1$ expression. $A, B$, Images of Erbb4 deletion in the NAccore and the histogram of statistical analysis ( $n=2395$ cells of 3 NAc-Con and 2023 cell of 4 NAc-CKO). Arrow, GFP-positive cells; arrowheads, GFP-negative cells. Scale bar, $10 \mu \mathrm{m}$. C, D, Immunoblots and quantification of ErbB4 and $G_{A B A} R \alpha 1$ protein from the NAc core of NAc-Con and NAc-CKO mice $(n=4) . E, F$, Images of GABA $R \alpha 1$ overexpression in NAc-cKO mice resembling cKO mice $(n=28$ cells from 4 NAc-Con and 50 cells from 5 NAc-cKO). Scale bar, $10 \mu \mathrm{m} . \mathbf{G}-\boldsymbol{K}, \mathrm{mIPSC}$ frequency and amplitude were increased in NAc-cKO mice with sample traces, histograms, and cumulative distribution plots $(n=28$ cells from 4 NAc-Con and 25 cells from 3 NAc-CKO). In this figure, all virus expression was restricted to the NAc core, so all data are included in the analysis. Statistical significance was calculated with two-tailed $t$ test for unpaired data $(\boldsymbol{B}, \boldsymbol{D}, \boldsymbol{F})$ or K-St test $(\boldsymbol{H}, \boldsymbol{J})$. All data are shown as mean $\pm \mathrm{SEM}$. NS, No significant difference.

showed that the ErbB4 transcript and protein are elevated in the prefrontal cortex of schizophrenic patients (Silberberg et al., 2006; Chong et al., 2008; Joshi et al., 2014) and that NRG1-induced phosphorylation of ErbB4 kinase is increased in the cortex of schizophrenia patients (Hahn et al., 2006). PSD-95 can interact with ErbB4 to regulate hippocampal neuregulin signaling (Huang et al., 2000) and ErbB4 deficits in hippocampus can induce glutamatergic hypofunction (Li et al., 2007). Previous studies about ErbB4 were mainly focused on prefrontal cortex and hippocampus, leaving ErbB4 function in other regions largely unknown (Huang et al., 2000; Neddens and Buonanno, 2010; Tan et al., 2011; Li et al., 2011; Del Pino et al., 2013). In this study, we characterize a novel role of ErbB4 in the striatum in regulating animal behavior.

The striatum includes multiple subregions. As for schizophrenia, patients with first-episode schizophrenia display a significant volumetric reduction in the NAc (Bois et al., 2015). In a schizophrenia rat model, aberrant high-frequency oscillations are recorded in the NAc (Goda et al., 2015). These studies highlight an important role for the NAc in mediating schizophrenia pathogenesis. The NAc core, but not the shell, has been reported to modulate risk-based decision making and cocaine-seeking behavior (Ito et al., 2004; Mai et al., 2015) and a lesion in the NAc core can induce persistent impulsive choice (Cardinal et al., 2001). These studies indicate that the core has a greater role in regulating cognitive and motivational behaviors than the shell. Our accumulating evidence suggests that Erbb4 deletion in the
NAc core could induce schizophrenia-like behaviors, thus supporting the role of the NAc core in mediating schizophrenia.

The DMS, but not the DLS, is reported to be involved in encoding action-outcome associations in instrumental conditioning (Yin et al., 2005). During the different phases of skill learning, the DMS was preferentially more engaged than the DLS in training (Yin et al., 2009). The DMS plays a more important role in mediating goal-directed behavior, whereas the DLS mainly participates in habit-driven behavior (Burton et al., 2015). Therefore, the DMS may take the prior place in modulating motivational behaviors than the DLS. Decreasing $G_{A B A} R$ $\alpha 1$ expression in the DMS failed to rescue most of the behavioral changes in Erbb4 mutant mice (Fig. $6 D-H$ ), although both the NAc and DMS showed $\alpha 1$ overexpression in Erbb4 mutant mice (Fig. 4E). This indicates that the NAc core and DMS may be involved in different aspects of these behaviors. Together, our results indicate that $\mathrm{GABA}_{\mathrm{A}} \mathrm{R} \alpha 1$ plays different roles in the NAc core and DMS and the NAc core may play a more important role in mediating schizophrenia.

\section{Novel cell-type-specific role of ErbB4 in the NAc MSNs in schizophrenia pathophysiology}

ErbB4 is mainly expressed in neurons in the brain, including PV-, somatostatin-, and cholecystokinin-expressing neurons (Vullhorst et al., 2009; Del Pino et al., 2013; Bean et al., 2014; Ahrens et al., 2015). Previous studies have described contributing roles of 

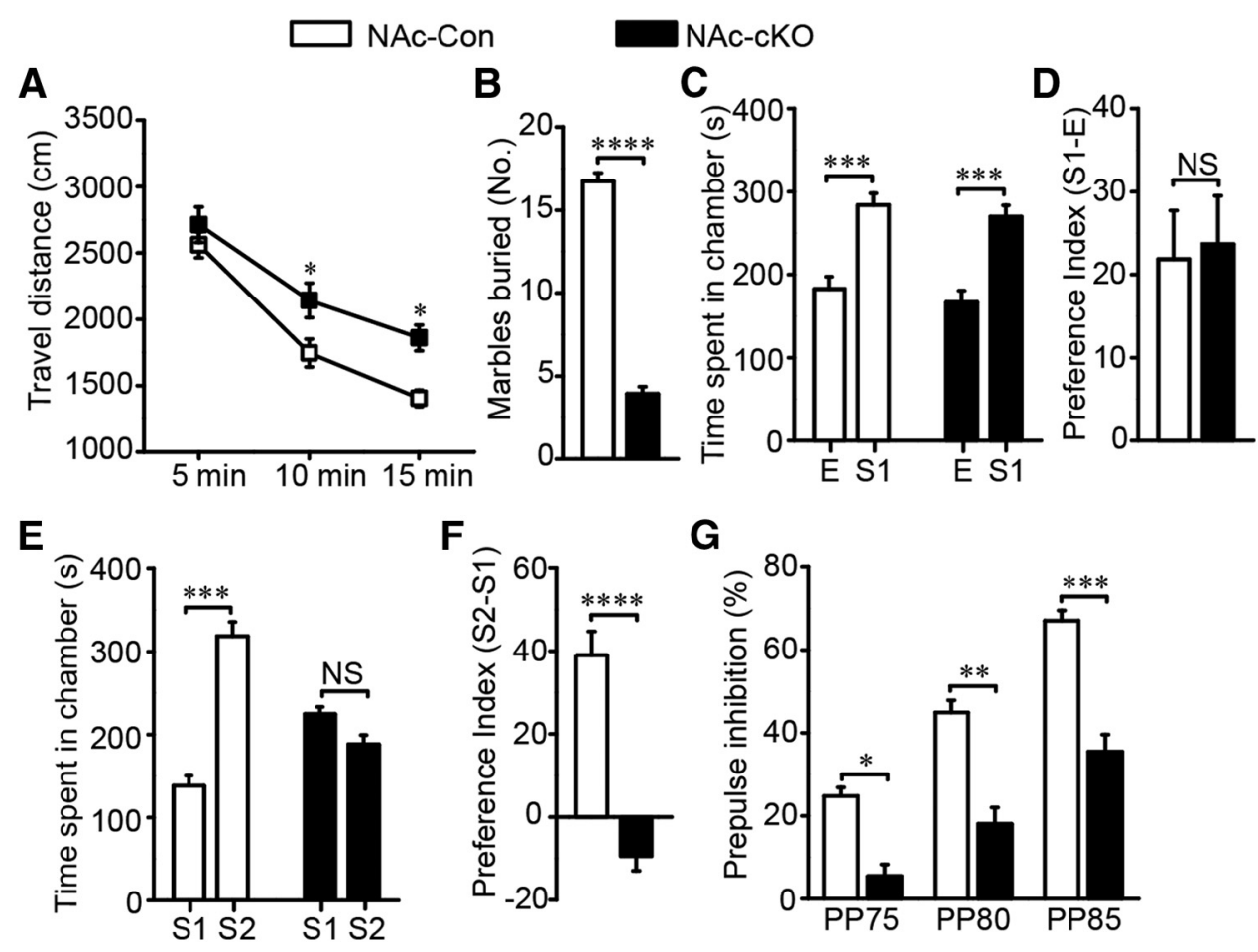

Figure 11. Specific Erbb4 deletion in the NAc core MSNs caused schizophrenia-like behavioral deficits. A, Hyperactivity of NAc-cK0 mice in open-field test $(n=16)$. B, Fewer marbles were buried by NAc-cKO mice $(n=15)$. C, NAc-cKO mice showed normal interests in the first stranger compared with the controls in three chamber test $(n=14$ NAc-Con and 13 NAc-cKO). $\boldsymbol{D}$, NAc-Con and NAc-cKO mice showed comparable preference to the first stranger ( $n=14 \mathrm{NAc-Con}$ and $13 \mathrm{NAc-CKO})$. $E$, NAc-cKO mice spent similar time with the first stranger and the second stranger, indicating

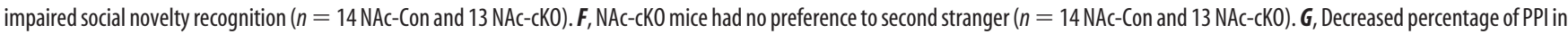
NAc-CKO mice $(n=15)$. In the behavior tests of the specific Erbb4 deletion in the NAc core, the virus expression of one NAc-cKO mouse was not limited to the NAc core, so its data were excluded for the behavior analysis. Statistical significance was determined by two-way ANOVA with Bonferroni post hoc test $(\boldsymbol{A}, \boldsymbol{C}, \boldsymbol{E}, \boldsymbol{G})$ or two-tailed $t$ test for unpaired data $(\boldsymbol{B}, \boldsymbol{D}, \boldsymbol{F})$. All data are shown as mean \pm SEM. NS, No significant difference.

ErbB4 deficiency in PV-expressing neurons to schizophrenia and epilepsy pathogenesis (Tan et al., 2011; Li et al., 2011; Del Pino et al., 2013), in somatostatin-expressing neurons to sensory selection (Ahrens et al., 2015), and in cholecystokinin-expressing neurons to spatial information coding (Del Pino et al., 2017). MSNs, the major GABAergic projection neurons in the NAc, express ErbB4 abundantly and mainly project to areas of the mesencephalon and basal ganglia (Salgado and Kaplitt, 2015). In this study, by manipulating ErbB4 expression in the MSNs, we characterized a novel cell-type-specific function of ErbB4 in regulating animal behavior. Integrating its output pattern with its major inputs from the limbic system, the NAc MSNs has been considered as the functional interface between the limbic and motor systems that plays important roles in reward, addiction, and depression (Krishnan and Nestler, 2008; McEwen et al., 2015; Volkow and Morales, 2015). Projections from VTA to NAc MSNs encode and predict key features of social behaviors (Gunaydin et al., 2014). Previous studies reported that locomotion, reward, and social interaction are abnormal in schizophrenia mouse models (Del Pino et al., 2013; Luo et al., 2014). Inspired by these findings, we suspected that MSNs in the NAc may be involved in these behaviors. Indeed, our results demonstrated that Erbb4 deletion in the NAc core MSNs can elicit schizophrenia-like behaviors including increased locomotion, abnormal marble-burying behavior, impaired social novelty recognition, and damaged sensorimotor gating function.

\section{Relationship between $\mathrm{GABA}_{\mathrm{A}} \mathrm{R} \alpha 1$ and schizophrenia} $\mathrm{GABA}_{\mathrm{A}} \mathrm{R} \alpha 1$ represents nearly $40 \%$ of all $\mathrm{GABA}_{\mathrm{A}}$ receptors and the expression of its gene has been shown to be altered in schizo- phrenia patients using a two-stage candidate gene association approach (Petryshen et al., 2005; Rudolph and Knoflach, 2011). $\alpha 1$ subunit mRNA levels are decreased in schizophrenia and epilepsy patients (Dean, 2002; Lewis and González-Burgos, 2008; Charych et al., 2009; Rico and Marín, 2011). In mice, it has been reported that ErbB4-null mice have diminished cortical $\mathrm{GABA}_{\mathrm{A}} \mathrm{R}$ $\alpha 1$ expression (Mitchell et al., 2013). However, we found that $\mathrm{GABA}_{\mathrm{A}} \mathrm{R} \alpha 1$ subunit expression was elevated in the striatum in the absence of ErbB4, which suggested there may be a regionspecific control of the $\mathrm{GABA}_{\mathrm{A}}$ receptor expression in schizophrenia. shRNA knock-down of $\mathrm{GABA}_{\mathrm{A}} \mathrm{R} \alpha 1$ in the NAc core of cKO mice confirmed that elevated $\mathrm{GABA}_{\mathrm{A}} \mathrm{R} \alpha 1$ expression in the NAc leads to altered physiology of local MSNs. In the context of normal $\mathrm{GABA}_{\mathrm{A}} \mathrm{R} \alpha 1$ expression in control animals, GABA $\mathrm{R} \alpha 1$ knock-down specifically in MSNs probably also influences neuronal physiology and animal behavior and will be informative about the general functions of this receptor in these neurons. However, investigation of $\mathrm{GABA}_{\mathrm{A}} \mathrm{R} \alpha 1$ physiological function is out of the scope of this study and will need more extensive efforts in future works.

Cortical and hippocampal ErbB4 may mediate schizophrenia by affecting interneuronal DISC1 or Src kinase, which regulates NMDA activity (Hahn et al., 2006; Pitcher et al., 2011; Seshadri et al., 2015). In contrast, our study proposea the NAc core as a crucial nucleus in ErbB4 participation of schizophrenia and demonstrated that $\mathrm{GABA}_{\mathrm{A}} \mathrm{R} \alpha 1$-dependent GABAergic synaptic transmission in striatal MSNs is the underlying mechanism. $\mathrm{GABA}_{\mathrm{A}}$ receptors have been tested as therapeutic targets for neurodevelopmental disorders such as autism and epilepsy (Braat and Kooy, 2015). We show that reducing $\mathrm{GABA}_{\mathrm{A}} \mathrm{R} \alpha 1$ expression in MSNs in the 
NAc core could reverse schizophrenia-like behaviors in Erbb4 mutant mice. The rescue effect of $\mathrm{GABA}_{\mathrm{A}} \mathrm{R} \alpha 1$ interference in Erbb4 mutant mice revealed the first molecular evidence for the regulation of schizophrenia by the NAc core.

\section{Presynaptic and postsynaptic involvement}

Deleting ErbB4 in striatal MSNs causes a significant increase in mIPSC amplitude and frequency via increased $\mathrm{GABA}_{A} \mathrm{R} \alpha 1$ membrane expression. Heterozygous $\alpha 1$ subunit deletion has been reported to reduce the amplitude and frequency of mIPSCs in the ventral basal nucleus, likely due to a partial compensatory mechanism that induces increased inhibitory input from the thalamic reticular nucleus (Zhou et al., 2015a). High-activity treated hippocampal neurons display increased mIPSC amplitude and frequency, whereas $\mathrm{GABA}_{\mathrm{A}}$ receptors accumulate before changes in GAD65 puncta size, indicating that retrograde signaling may mediate this progress (Rannals and Kapur, 2011). Elevated postsynaptic activity is required for the increase in mIPSC amplitude and frequency in cultured hippocampal neurons caused by GAD65, vGAT, and GABA $\mathrm{R} \alpha 1$ overexpression. Downregulating BDNF in postsynaptic neurons prevents mIPSC enhancement, suggesting that retrograde signaling participates in this process (Peng et al., 2010). We found that Erbb4 deletion increased both mIPSC amplitude and frequency, which were rescued by the interference of $\mathrm{GABA}_{\mathrm{A}} \mathrm{R} \alpha 1$ expression, indicating the possible involvement of a compensatory input mechanism or retrograde signaling pathway.

In conclusion, our work demonstratea that ErbB4 signaling in the NAc core is involved in the pathophysiology of schizophrenia and that the $\mathrm{GABA}_{\mathrm{A}} \mathrm{R} \alpha 1$ subunit may serve as a new molecular target in mediating psychiatric disease development in the NAc core.

\section{References}

Agim ZS, Esendal M, Briollais L, Uyan O, Meschian M, Martinez LA, Ding Y, Basak AN, Ozcelik H (2013) Discovery, validation and characterization of Erbb4 and Nrg1 haplotypes using data from three genome-wide association studies of schizophrenia. PLoS One 8:e53042. CrossRef Medline

Ahrens S, Jaramillo S, Yu K, Ghosh S, Hwang GR, Paik R, Lai C, He M, Huang ZJ, Li B (2015) ErbB4 regulation of a thalamic reticular nucleus circuit for sensory selection. Nat Neurosci 18:104-111. CrossRef Medline

Balleine BW, Delgado MR, Hikosaka O (2007) The role of the dorsal striatum in reward and decision-making. J Neurosci 27:8161-8165. CrossRef Medline

Bean JC, Lin TW, Sathyamurthy A, Liu F, Yin DM, Xiong WC, Mei L (2014) Genetic labeling reveals novel cellular targets of schizophrenia susceptibility gene: distribution of GABA and non-GABA ErbB4-positive cells in adult mouse brain. J Neurosci 34:13549-13566. CrossRef Medline

Belforte JE, Zsiros V, Sklar ER, Jiang Z, Yu G, Li Y, Quinlan EM, Nakazawa K (2010) Postnatal NMDA receptor ablation in corticolimbic interneurons confers schizophrenia-like phenotypes. Nat Neurosci 13:76-83. CrossRef Medline

Bois C, Levita L, Ripp I, Owens DC, Johnstone EC, Whalley HC, Lawrie SM (2015) Hippocampal, amygdala and nucleus accumbens volume in firstepisode schizophrenia patients and individuals at high familial risk: a cross-sectional comparison. Schizophrenia research 165:45-51. CrossRef Medline

Braat S, Kooy RF (2015) The GABA(A) receptor as a therapeutic target for neurodevelopmental disorders. Neuron 86:1119-1130. CrossRef Medline

Burton AC, Nakamura K, Roesch MR (2015) From ventral-medial to dorsal-lateral striatum: neural correlates of reward-guided decisionmaking. Neurobiol Learn Mem 117:51-59. CrossRef Medline

Cardinal RN, Pennicott DR, Sugathapala CL, Robbins TW, Everitt BJ (2001) Impulsive choice induced in rats by lesions of the nucleus accumbens core. Science 292:2499-2501. CrossRef Medline

Charych EI, Liu F, Moss SJ, Brandon NJ (2009) GABAA receptors and their associated proteins: Implications in the etiology and treatment of schizophre- nia and related disorders. Neuropharmacology 57:481-495. CrossRef Medline

Chong VZ, Thompson M, Beltaifa S, Webster MJ, Law AJ, Weickert CS (2008) Elevated neuregulin-1 and ErbB4 protein in the prefrontal cortex of schizophrenic patients. Schizophr Res 100:270-280. CrossRef Medline

Christoffel DJ, et al. (2015) Excitatory transmission at thalamo-striatal synapses mediates susceptibility to social stress. Nat Neurosci 18:962-964. CrossRef Medline

Crittenden JR, Graybiel AM (2011) Basal Ganglia disorders associated with imbalances in the striatal striosome and matrix compartments. Front Neuroanat 5:59. CrossRef Medline

Deacon RM (2006) Digging and marble burying in mice: simple methods for in vivo identification of biological impacts. Nat Protoc 1:122-124. CrossRef Medline

Dean B (2002) Understanding the pathology of schizophrenia: recent advances from the study of the molecular architecture of postmortem CNS tissue. Postgrad Med J 78:142-148. CrossRef Medline

Del Pino I, García-Frigola C, Dehorter N, Brotons-Mas JR, Alvarez-Salvado E, Martínez de Lagrán M, Ciceri G, Gabaldón MV, Moratal D, Dierssen M, Canals S, Marín O, Rico B (2013) Erbb4 deletion from fast-spiking interneurons causes schizophrenia-like phenotypes. Neuron 79:11521168. CrossRef Medline

Del Pino I, Brotons-Mas JR, Marques-Smith A, Marighetto A, Frick A, Marín O, Rico B (2017) Abnormal wiring of CCK + basket cells disrupts spatial information coding. Nat Neurosci 20:784-792. CrossRef Medline

Fazzari P, Paternain AV, Valiente M, Pla R, Luján R, Lloyd K, Lerma J, Marín O, Rico B (2010) Control of cortical GABA circuitry development by Nrg1 and ErbB4 signalling. Nature 464:1376-1380. CrossRef Medline

Floresco SB (2015) The nucleus accumbens: an interface between cognition, emotion, and action. Annu Rev Psychol 66:25-52. CrossRef Medline

García-Rivello H, Taranda J, Said M, Cabeza-Meckert P, Vila-Petroff M, Scaglione J, Ghio S, Chen J, Lai C, Laguens RP, Lloyd KC, Hertig CM (2005) Dilated cardiomyopathy in Erb-b4-deficient ventricular muscle. Am J Physiol Heart Circ Physiol 289:H1153-H1160. CrossRef Medline

Gerlai R, Pisacane P, Erickson S (2000) Heregulin, but not ErbB2 or ErbB3, heterozygous mutant mice exhibit hyperactivity in multiple behavioral tasks. Behav Brain Res 109:219-227. CrossRef Medline

Goda SA, Olszewski M, Piasecka J, Rejniak K, Whittington MA, Kasicki S, Hunt MJ (2015) Aberrant high frequency oscillations recorded in the rat nucleus accumbens in the methylazoxymethanol acetate neurodevelopmental model of schizophrenia. Prog Neuropsychopharmacol Biol Psychiatry 61:44-51. CrossRef Medline

Golub MS, Germann SL, Lloyd KC (2004) Behavioral characteristics of a nervous system-specific erbB4 knock-out mouse. Behav Brain Res 153: 159-170. CrossRef Medline

Gunaydin LA, Grosenick L, Finkelstein JC, Kauvar IV, Fenno LE, Adhikari A, Lammel S, Mirzabekov JJ, Airan RD, Zalocusky KA, Tye KM, Anikeeva P, Malenka RC, Deisseroth K (2014) Natural neural projection dynamics underlying social behavior. Cell 157:1535-1551. CrossRef Medline

Haber SN (2003) The primate basal ganglia: parallel and integrative networks. J Chem Neuroanat 26:317-330. CrossRef Medline

Hahn CG, Wang HY, Cho DS, Talbot K, Gur RE, Berrettini WH, Bakshi K, Kamins J, Borgmann-Winter KE, Siegel SJ, Gallop RJ, Arnold SE (2006) Altered neuregulin 1-erbB4 signaling contributes to NMDA receptor hypofunction in schizophrenia. Nat Med 12:824-828. CrossRef Medline

Huang YZ, Won S, Ali DW, Wang Q, Tanowitz M, Du QS, Pelkey KA, Yang DJ, Xiong WC, Salter MW, Mei L (2000) Regulation of neuregulin signaling by PSD-95 interacting with ErbB4 at CNS synapses. Neuron 26 : 443-455. CrossRef Medline

Ito R, Robbins TW, Everitt BJ (2004) Differential control over cocaineseeking behavior by nucleus accumbens core and shell. Nat Neurosci 7:389-397. CrossRef Medline

Jahanshahi M, Obeso I, Rothwell JC, Obeso JA (2015) A fronto-striatosubthalamic-pallidal network for goal-directed and habitual inhibition. Nat Rev Neurosci 16:719-732. CrossRef Medline

Joshi D, Fullerton JM, Weickert CS (2014) Elevated ErbB4 mRNA is related to interneuron deficit in prefrontal cortex in schizophrenia. J Psychiatr Res 53:125-132. CrossRef Medline

Kreitzer AC (2009) Physiology and pharmacology of striatal neurons. Annu Rev Neurosci 32:127-147. CrossRef Medline

Krishnan V, Nestler EJ (2008) The molecular neurobiology of depression. Nature 455:894-902. CrossRef Medline 
Lewis DA, González-Burgos G (2008) Neuroplasticity of neocortical circuits in schizophrenia. Neuropsychopharmacology 33:141-165. Medline

Li B, Woo RS, Mei L, Malinow R (2007) The neuregulin-1 receptor erbB4 controls glutamatergic synapse maturation and plasticity. Neuron 54: 583-597. CrossRef Medline

Li KX, Lu YM, Xu ZH, Zhang J, Zhu JM, Zhang JM, Cao SX, Chen XJ, Chen Z, Luo JH, Duan S, Li XM (2011) Neuregulin 1 regulates excitability of fast-spiking neurons through Kv1.1 and acts in epilepsy. Nat Neurosci 15:267-273. CrossRef Medline

Lu CL, Wang YC, Chen JY, Lai IC, Liou YJ (2010) Support for the involvement of the ERBB4 gene in schizophrenia: a genetic association analysis. Neurosci Lett 481:120-125. CrossRef Medline

Luo X, He W, Hu X, Yan R (2014) Reversible overexpression of bace1cleaved neuregulin-1 N-terminal fragment induces schizophrenia-like phenotypes in mice. Biol Psychiatry 76:120-127. CrossRef Medline

Madisen L, et al. (2015) Transgenic mice for intersectional targeting of neural sensors and effectors with high specificity and performance. Neuron 85:942-958. CrossRef Medline

Mai B, Sommer S, Hauber W (2015) Dopamine D1/D2 receptor activity in the nucleus accumbens core but not in the nucleus accumbens shell and orbitofrontal cortex modulates risk-based decision making. Int J Neuropsychopharmacol 18:pyv043. CrossRef Medline

McEwen BS, Bowles NP, Gray JD, Hill MN, Hunter RG, Karatsoreos IN, Nasca C (2015) Mechanisms of stress in the brain. Nat Neurosci 18: 1353-1363. CrossRef Medline

Mehler-Wex C, Riederer P, Gerlach M (2006) Dopaminergic dysbalance in distinct basal ganglia neurocircuits: implications for the pathophysiology of Parkinson's disease, schizophrenia and attention deficit hyperactivity disorder. Neurotox Res 10:167-179. CrossRef Medline

Mei L, Xiong WC (2008) Neuregulin 1 in neural development, synaptic plasticity and schizophrenia. Nat Rev Neurosci 9:437-452. CrossRef Medline

Mitchell RM, Janssen MJ, Karavanova I, Vullhorst D, Furth K, Makusky A, Markey SP, and Buonanno A (2013) ErbB4 reduces synaptic GABAA currents independent of its receptor tyrosine kinase activity. Proc Natl Acad Sci 110:19603-19608. CrossRef Medline

Miyoshi G, Hjerling-Leffler J, Karayannis T, Sousa VH, Butt SJ, Battiste J, Johnson JE, Machold RP, Fishell G (2010) Genetic fate mapping reveals that the caudal ganglionic eminence produces a large and diverse population of superficial cortical interneurons. J Neurosci 30:1582-1594. CrossRef Medline

Neddens J, Buonanno A (2010) Selective populations of hippocampal interneurons express ErbB4 and their number and distribution is altered in ErbB4 knockout mice. Hippocampus 20:724-744. CrossRef Medline

Nicodemus KK, Luna A, Vakkalanka R, Goldberg T, Egan M, Straub RE, Weinberger DR (2006) Further evidence for association between ErbB4 and schizophrenia and influence on cognitive intermediate phenotypes in healthy controls. Mol Psychiatry 11:1062-1065. CrossRef Medline

Okada M, Onodera K, Van Renterghem C, Sieghart W, Takahashi T (2000) Functional correlation of GABA(A) receptor alpha subunits expression with the properties of IPSCs in the developing thalamus. J Neurosci 20: 2202-2208. Medline

Okada N, et al. (2016) Abnormal asymmetries in subcortical brain volume in schizophrenia. Mol Psychiatry 21:1460-1466. CrossRef Medline

Park SJ, Lee JY, Kim SJ, Choi SY, Yune TY, Ryu JH (2015) Toll-like receptor-2 deficiency induces schizophrenia-like behaviors in mice. Sci Rep 5:8502. CrossRef Medline

Peng YR, Zeng SY, Song HL, Li MY, Yamada MK, Yu X (2010) Postsynaptic spiking homeostatically induces cell-autonomous regulation of inhibitory inputs via retrograde signaling. J Neurosci 30:16220-16231. CrossRef Medline

Petryshen TL, et al. (2005) Genetic investigation of chromosome 5q GABAA receptor subunit genes in schizophrenia. Mol Psychiatry 10:1074-1088, 1057. Medline

Pitcher GM, Kalia LV, Ng D, Goodfellow NM, Yee KT, Lambe EK, Salter MW (2011) Schizophrenia susceptibility pathway neuregulin 1-ErbB4 suppresses Src upregulation of NMDA receptors. Nat Med 17:470-478. CrossRef Medline

Rannals MD, Kapur J (2011) Homeostatic strengthening of inhibitory synapses is mediated by the accumulation of GABA(A) receptors. J Neurosci 31:17701-17712. CrossRef Medline
Rauch SL, Dougherty DD, Malone D, Rezai A, Friehs G, Fischman AJ, Alpert NM, Haber SN, Stypulkowski PH, Rise MT, Rasmussen SA, Greenberg BD (2006) A functional neuroimaging investigation of deep brain stimulation in patients with obsessive-compulsive disorder. J Neurosurg 104: 558-565. CrossRef Medline

Rico B, Marín O (2011) Neuregulin signaling, cortical circuitry development and schizophrenia. Curr Opin Genet Dev 21:262-270. CrossRef Medline

Rudolph U, Knoflach F (2011) Beyond classical benzodiazepines: novel therapeutic potential of GABAA receptor subtypes. Nat Rev Drug Discov 10:685-697. CrossRef Medline

Russo SJ, Nestler EJ (2013) The brain reward circuitry in mood disorders. Nat Rev Neurosci 14:609-625. CrossRef Medline

Salgado S, Kaplitt MG (2015) The nucleus accumbens: a comprehensive review. Stereotact Funct Neurosurg 93:75-93. CrossRef Medline

Seshadri S, Faust T, Ishizuka K, Delevich K, Chung Y, Kim SH, Cowles M, Niwa M, Jaaro-Peled H, Tomoda T, Lai C, Anton ES, Li B, Sawa A (2015) Interneuronal DISC1 regulates NRG1-ErbB4 signalling and excitatoryinhibitory synapse formation in the mature cortex. Nat Commun 6:10118. CrossRef Medline

Shi J, et al. (2009) Common variants on chromosome 6p22.1 are associated with schizophrenia. Nature 460:753-757. Medline

Silberberg G, Darvasi A, Pinkas-Kramarski R, Navon R (2006) The involvement of ErbB4 with schizophrenia: association and expression studies. Am J Med Genet B Neuropsychiatr Genet 141B:142-148. CrossRef Medline

Simpson EH, Kellendonk C, Kandel E (2010) A possible role for the striatum in the pathogenesis of the cognitive symptoms of schizophrenia. Neuron 65:585-596. CrossRef Medline

Tan GH, Liu YY, Hu XL, Yin DM, Mei L, Xiong ZQ (2011) Neuregulin 1 represses limbic epileptogenesis through ErbB4 in parvalbumin-expressing interneurons. Nat Neurosci 15:258-266. CrossRef Medline

Vicini S, Ferguson C, Prybylowski K, Kralic J, Morrow AL, Homanics GE (2001) GABA(A) receptor alphal subunit deletion prevents developmental changes of inhibitory synaptic currents in cerebellar neurons. J Neurosci 21:3009-3016. Medline

Volkow ND, Morales M (2015) The brain on drugs: from reward to addiction. Cell 162:712-725. CrossRef Medline

Vullhorst D, Neddens J, Karavanova I, Tricoire L, Petralia RS, McBain CJ, Buonanno A (2009) Selective expression of ErbB4 in interneurons, but not pyramidal cells, of the rodent hippocampus. J Neurosci 29:1225512264. CrossRef Medline

Walsh T, et al. (2008) Rare structural variants disrupt multiple genes in neurodevelopmental pathways in schizophrenia. Science 320:539-543. CrossRef Medline

Yang JM, Zhang J, Chen XJ, Geng HY, Ye M, Spitzer NC, Luo JH, Duan SM, Li XM (2013) Development of GABA circuitry of fast-spiking basket interneurons in the medial prefrontal cortex of erbb4-mutant mice. J Neurosci 33:19724-19733. CrossRef Medline

Yang JM, Zhang J, Yu YQ, Duan S, Li XM (2014) Postnatal development of 2 microcircuits involving fast-spiking interneurons in the mouse prefrontal cortex. Cereb Cortex 24:98-109. CrossRef Medline

Yin HH, Knowlton BJ, Balleine BW (2005) Blockade of NMDA receptors in the dorsomedial striatum prevents action-outcome learning in instrumental conditioning. Eur J Neurosci 22:505-512. CrossRef Medline

Yin HH, Mulcare SP, Hilário MR, Clouse E, Holloway T, Davis MI, Hansson AC, Lovinger DM, Costa RM (2009) Dynamic reorganization of striatal circuits during the acquisition and consolidation of a skill. Nat Neurosci 12:333-341. CrossRef Medline

Zerucha T, Stühmer T, Hatch G, Park BK, Long Q, Yu G, Gambarotta A, Schultz JR, Rubenstein JL, Ekker M (2000) A highly conserved enhancer in the Dlx5/Dlx6 intergenic region is the site of cross-regulatory interactions between Dlx genes in the embryonic forebrain. J Neurosci 20:709721. Medline

Zhou C, Ding L, Deel ME, Ferrick EA, Emeson RB, Gallagher MJ (2015a) Altered intrathalamic GABAA neurotransmission in a mouse model of a human genetic absence epilepsy syndrome. Neurobiol Dis 73:407-417. CrossRef Medline

Zhou Y, Fan L, Qiu C, Jiang T (2015b) Prefrontal cortex and the dysconnectivity hypothesis of schizophrenia. Neurosci Bull 31:207-219. CrossRef Medline 